\title{
An examination of the Antimicrobial and Anticancer Properties of Khaya senegalensis (Desr.) A. Juss. Bark Extracts
}

\author{
Camille Rabadeaux ${ }^{1,2}$, Lou Vallette ${ }^{1,2}$, Joseph Sirdaarta ${ }^{1,3}$, Craig Davis ${ }^{4,5}$, Ian Edwin Cock $\mathbf{k}^{1,3^{*}}$
}

Camille Rabadeaux ${ }^{1,2}$, Lou

Vallette ${ }^{1,2}$, Joseph Sirdaarta, ${ }^{1,3}$ Craig Davis ${ }^{4,5}$, Ian Edwin Cock ${ }^{1,3^{*}}$ 'Environmental Futures Research Institute, Griffith University, Brisbane, AUSTRALIA.

${ }^{2}$ School of Biology, Ecole de Biologie Industrielle (EBI), Cergy, FRANCE. ${ }^{3}$ School of Natural Sciences, Griffith University, Brisbane, AUSTRALIA. ${ }^{4}$ Botanical Medicine Research Institute, Brisbane, AUSTRALIA.

${ }^{5}$ Bioextracts P/L, Brisbane, AUSTRALIA.

\section{Correspondence}

\section{lan Edwin Cock}

Environmental Futures Research Institute, Griffith University, Brisbane, Australia

School of Natural Sciences, Griffith University, Brisbane, Australia

Phone number: +61 737357637

$$
\text { Fax: }+61737355282
$$

E-mail: I.Cock@griffith.edu.au

\section{History}

- Submission Date: 02-12-2016;

- Review completed: 05-01-2017;

- Accepted Date: 02-02-2017.

\section{DOI : 10.5530/pj.2017.4.82}

Article Available online http://www.phcogj.com/v9/i4

\section{Copyright}

(c) 2016 Phcog.Net. This is an openaccess article distributed under the terms of the Creative Commons Attribution 4.0 International license.

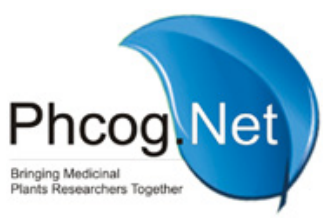

\begin{abstract}
Background: Khaya senegalensis (Desr.) A. Juss. is a common component of the pharmacopeia's of multiple African groupings which inhabit the areas in which it grows. Amongst these groups there is a myriad of medicinal uses in the treatment of a wide variety of bacterial, fungal and protozoal infections, as well as in the treatment of cancers. This study was undertaken to test $K$. senegalensis bark extracts for the ability to inhibit microbial and cancer cell growth, and thus to validate traditional African medicinal usage of this plant in treating a variety of diseases. Materials and Methods: K. senegalensis bark powder was extracted by both solvent maceration and subcritical fluid extraction (SFE). The extracts were tested for the ability to inhibit bacterial and G. duodenalis growth. Inhibition of Caco-2 and HeLa cancer cells was evaluated using MTS-based colorimetric cell proliferation assays. Toxicity was evaluated using an Artemia franciscana nauplii bioassay and GC-MS headspace analysis was used to identify phytochemical components. Results: $K$. senegalensis bark extracts displayed strong inhibitory activity against bacterial triggers of several autoimmune inflammatory diseases. The growth inhibitory activity of the methanolic and subcritical extracts was particularly noteworthy against $P$. mirabilis (MIC values of 185 and $211 \mu \mathrm{g} / \mathrm{mL}$, respectively against the reference strains). These extracts were similarly potent growth inhibitors of $K$. pneumoniae and $A$. baylyi, and were moderate inhibitors ( $\mathrm{MIC}>1000 \mu \mathrm{g} / \mathrm{mL}$ ) of $P$. aeruginosa and $S$. pyogenes growth. The methanolic and subcritical $K$. senegalensis extracts were also potent inhibitors of G. duodenalis (187 and $328 \mu \mathrm{g} / \mathrm{mL}$, respectively), as well as Caco-2 (268 and $470 \mu \mathrm{g} / \mathrm{mL}$, respectively) and HeLa carcinomas (155 and $174 \mu \mathrm{g} / \mathrm{mL}$, respectively). GC-MS analysis of the SFE extract revealed relative abundances of a variety of mono- and sesquiterpenoids. Furthermore, all $K$. senegalensis bark extracts were non-toxic in the Artemia franciscana toxicity assay, indicating their safety for therapeutic use. Conclusion: These studies validate traditional African therapeutic usage of $K$. senegalensis in the treatment of microbial infections, autoimmune inflammatory diseases and some cancers.
\end{abstract}

Key words: African mahogany, Meliaceae, Sub-critical fluid extraction, Anti bacterial activity, Giardia duodenalis, Anti-proliferative activity, Anti-cancer activity, Terpenoid.

\section{INTRODUCTION}

Plants have been used for thousands of years as medicines for treating a variety of different diseases and medical complaints by most, if not all, civilisations. The traditional uses and therapeutic properties of many African plants have been well documented. ${ }^{1,2}$ For many African plant medicines, the traditional uses have been validated via bioactivity and phytochemical studies. Several African plant-derived medicines have also found a place in allopathic medicine. For example, the anti-tumour agents vinblastine and vincristine (derived from Catharanthus roseus) are used in the treatment of a variety of tumours. ${ }^{1}$ The medicinal properties of other African plant species are less well understood despite a long history of ethnobotanical usage. Khaya senegalensis (Desr.) A.Juss. (family Meliaceae; commonly known as African mahogany, Gambia mahogany, Senegal mahogany, Khaya wood) is a tall evergreen African tree with a wide geographical range, occurring from Central Africa to Western Africa. ${ }^{3}$ It is native to Benin, Burkina Faso, Cameroon, Central African Republic, Chad,
Côte d'Ivoire, Democratic Republic of Congo, Gabon, Gambia, Ghana, Guinea, Guinea-Bissau, Mali, Niger, Nigeria, Republic of Congo, Senegal, Sierra Leone, Sudan, South Sedan, Togo and Uganda, usually growing in high rainfall woodlands and alongside rivers.

The therapeutic value of $K$. senegalensis is recognised by multiple ethnic groupings across the regions in which it occurs for the treatment of a wide range of diseases/conditions (Table 1). Whilst the stem bark is most often cited as having therapeutic properties, multiple parts of the $K$. senegalensis tree have been used in traditional healing systems. Decoctions prepared from the stem bark were used to treat dermatitis and other skin diseases, diarrhoea and dysentery, fever, jaundice, malaria and sexually-transmitted diseases. ${ }^{4,5}$ Bark decoctions are also useful as an anti-helminth, particularly in treating hookworm and tapeworm infestations. ${ }^{4,5}$ 
Despite, the widespread therapeutic usage of $K$. senegalensis, there have been limited rigorous scientific studies to verify the ethnomedicinal properties of this plant. Instead, many studies have examined the phytochemistry without linking the components to bioactivity studies. Whilst several studies verifying bioactivities associated with ethnobotanical usage exist, many of these reports have focussed on the bark, and to a lesser extent, the leaf. Bark extracts have been reported to have good anticancer $^{6,13,14}$ and anti-inflammatory properties ${ }^{6}$ are good immunostimulants ${ }^{11}$ and are insect deterrents. ${ }^{8} \mathrm{~K}$. senegalensis bark extracts have potential in the treatment of diabetes and have been reported to have anti-hyperglycemic activity comparable to glibenclamide. ${ }^{12}$ Furthermore, K. senegalensis stem bark extracts have been shown to have high antioxidant content ${ }^{6}$ further indicating the therapeutic potential of this species.

Several studies have also examined the antimicrobial properties of $K$. senegalensis. The anti-protozoal properties have been particularly well established. Solvent extracts of several plant parts have been reported to inhibit the growth of Plasmodium falciparum, ${ }^{15}$ Trypanosoma evansi and Trypanosoma bruce $i^{16}$ and several Leishmania spp. ${ }^{11}$ Interestingly, we were unable to find any studies examining the effects of $K$. senegalensis extracts on the gastrointestinal protozoal parasite Giardia duodenalis. Several studies have also reported bacterial growth inhibitory properties for K. senegalensis extracts. ${ }^{910}$ Both leaf and bark extracts inhibited the growth of the gram positive bacteria Staphylococcus aureus and Streptococcus faecalis but were ineffective against the gram negative bacteria, Escherichia coli. ${ }^{9}$ However, the MIC values reported in that study (4000$8000 \mu \mathrm{g} / \mathrm{mL}$ ) are indicative of only low to moderate growth inhibitory activity. A different study reported antibacterial activity against a broader bacterial panel, although that study only tested a single extract concentration and did not report MIC values, making it impossible to compare the efficacy with other studies. ${ }^{10}$

Whilst further studies are required to fully characterise the phytochemistry of $K$. senegalensis, a number of interesting compounds have already been identified. The bark, ${ }^{17,18}$ leaves $^{19}$ and fruit ${ }^{8}$ contain significant quantities of a variety of limonoids (Figure 1a). The bark also contains substantial levels of khayanolides (Figure $1 \mathrm{~b})^{20,21}$ and senagalene triterpenoids (Figure 1d) ${ }^{20}$ Angolensates have also been reported in the fruit. ${ }^{8}$ Furthermore, the dimeric proanthocyanidins proanthocyanidin B3 (Figure 1e) and fisetinidol-(4a,6)-catechin (Figure 1f) were detected in $K$. senegalensis extracts [Kayser and Abreu, 2001], although that report does not state which part of the plant was investigated. Several similar compounds of these classes have been reported to have antimicrobial and anticancer therapeutic bioactivities. ${ }^{22}$

Despite the promising earlier studies, there has been a relative lack of recent reports into the therapeutic properties of this species. Furthermore, we were unable to find any previous studies examining the therapeutic properties and phytochemistry of $K$. senegalensis bark. The current study was undertaken to extend the earlier antibacterial studies of $K$. senegalensis by examining the growth inhibitory properties of bark extracts against a panel of bacterial triggers of autoimmune inflammatory diseases. The ability to inhibit the growth of the gastrointestinal parasite Giardia duodenalis was also evaluated for the first time. Furthermore, the anticancer activity of $K$. senegalensis bark extracts was evaluated against 2 cancer cell lines, extending earlier reports of anticancer activity for $K$. senegalensis extracts. The toxicity of the K. senegalensis bark extracts was also determined to evaluate their usefulness as medicinal agents.

\section{MATERIALS AND METHODS}

\section{Laboratory scale extraction}

K. senegalensis bark was obtained from African Mahogany [Australia] Pty Ltd and stored at $-30^{\circ} \mathrm{C}$ until processing. The shavings were thawed at room temperature, cut into small pieces and thoroughly dried in a Sunbeam food dehydrator. The dried pieces were subsequently ground into a coarse powder and extracted by standardised methods. ${ }^{23}$ Briefly, an amount of $1 \mathrm{~g}$ of powdered plant material was weighed into each of five tubes and five different extracts were prepared by adding $50 \mathrm{~mL}$ of methanol, water, ethyl acetate, chloroform or hexane, respectively. All solvents were obtained from Ajax and were AR grade. The ground dried bark shavings were extracted individually in each solvent for 24 hours at $4^{\circ} \mathrm{C}$ with gentle shaking. The extracts were filtered through filter paper (Whatman No. 54) under vacuum, followed by drying by centrifugal evaporation in an Eppendorf concentrator 5301. The resultant dry extract was weighed and redissolved in $10 \mathrm{~mL}$ of deionised water.

\section{Sub-critical fluid extraction (SFE) of $K$. senegalensis with dimethyl ether (DME)}

The ground $K$. senegalensis bark was extracted by subcritical extraction techniques as previously described. ${ }^{24}$ Briefly, the ground plant material was packed into the biomass chamber of the extraction system. The system was sealed and evacuated before the plant material in the biomass chamber was covered with compressed solvent (dimethyl ether). The compressed gas was cycled repeatedly across the plant material for 20 minutes. Subcritical DME extraction was carried out at room temperature and at a pressure of $500 \mathrm{MPa}$. The solvent was recycled and stored in a solvent reservoir. After the compressed dimethyl ether gas had been removed, the material that had been extracted from the plant biomass was collected in a separate vessel.

\section{Qualitative phytochemical studies}

Phytochemical analysis of the K. senegalensis extracts for the presence of saponins, phenolic compounds, flavonoids, phytosteroids, triterpenoids, cardiac glycosides, anthraquinones, tannins and alkaloids was conducted by previously described assays. ${ }^{25-27}$

\section{Antibacterial screening}

\section{Test microorganisms}

All media was supplied by Oxoid Ltd. Australia. Reference strains of Acinitobacter baylyi (ATCC33304), Klebsiella pneumoniae (ATCC31488), Proteus mirabilis (ATCC21721), Proteus vulgaris (ATCC21719) and Pseudomonas aeruginosa (ATCC39324) were purchased from American Tissue Culture Collection, USA. All other clinical microbial strains were obtained from the School of Natural Sciences teaching laboratory, Griffith University. All stock cultures were subcultured and maintained in nutrient broth at $4^{\circ} \mathrm{C}$.

\section{Evaluation of antimicrobial activity}

Antimicrobial activity of all plant extracts was determined using a modified disc diffusion method. ${ }^{28-30}$ Briefly, $100 \mu \mathrm{L}$ of the test bacteria were grown in $10 \mathrm{~mL}$ of fresh nutrient broth until they reached a count of approximately $10^{8}$ cells $/ \mathrm{mL}$ (as determined by direct microscopic determination). One hundred microliters of microbial suspension was subsequently spread onto the agar plates. The extracts were tested using $5 \mathrm{~mm}$ sterilised filter paper discs. Discs were infused with $10 \mu \mathrm{L}$ of the test sample, allowed to dry and placed onto the inoculated plates. The plates were allowed to stand at $4^{\circ} \mathrm{C}$ for 2 hours before incubation with the test microbial agents. The plates were then incubated at $30^{\circ} \mathrm{C}$ for 24 hours and the diameters of the inhibition zones were measured in millimetres. All measurements were to the closest whole millimetre. Each antimicrobial assay was performed in at least triplicate and mean values were determined. Standard discs of ampicillin $(10 \mu \mathrm{g})$ were obtained from Oxoid Ltd., Australia and served as positive controls. Filter discs infused with $10 \mu \mathrm{L}$ of distilled water were used as negative controls. 


\section{Minimum inhibitory concentration (MIC) determination}

The minimum inhibitory concentration (MIC) of the K. senegalensis extracts were determined by a modified disc diffusion method. ${ }^{31,32}$ The plant extracts were diluted in deionised water across a concentration range of $5 \mathrm{mg} / \mathrm{mL}$ to $0.1 \mathrm{mg} / \mathrm{mL}$. Discs were infused with $10 \mu \mathrm{L}$ of the test dilutions, allowed to dry and placed onto inoculated plates. The assay was performed as outlined above and graphs of the zone of inhibition versus concentration were plotted for each extract. Linear regression was used to calculate the MIC values.

\section{Inhibitory bioactivity against Giardia duodenalis trophozoites}

\section{Parasite culture}

The reference Giardia duodenalis trophozoite strain (ATTC203333) used in this study was purchased from American Tissue Culture Collection, USA. G. duodenalis tropozoites were maintained and subcultured anaerobically at $37^{\circ} \mathrm{C}$ in TYI-S-33 growth media supplemented with $1 \%$ bovine bile (Sigma), 10\% Serum Supreme (Cambrex Bioproducts) and 200IU/mL penicillin/200 $\mu \mathrm{g} / \mathrm{mL}$ streptomycin (Invitrogen, USA). Confluent mid log phase cultures were passaged every 2 days by chilling the cultures on ice for a minimum of $10 \mathrm{~min}$, followed by vortexing to dislodge the adherent trophozoites from the walls of the culture vessel. Fresh culture media $(5 \mathrm{~mL})$ was seeded with approximately $1 \times 10^{5}$ trophozoites for each passage.

\section{Evaluation of anti-Giardial activity}

Anti-Giardial activity of the $K$. senegalensis extracts was assessed by direct enumeration of parasite numbers in the presence or absence of extract $^{33,34}$ For each test, aliquots of the trophozoite suspension $(70 \mu \mathrm{L})$ containing approximately $1 \times 10^{5}$ trophozoites were added to the wells of a 96 well plate. A volume of $30 \mu \mathrm{L}$ of the test extracts or the vehicle solvent or culture media (for the negative controls) was added to individual wells and the plates were incubated anaerobically at $37^{\circ} \mathrm{C}$ for 8 hours in a humidified anaerobic atmosphere. Following the $8 \mathrm{~h}$ incubation, all tubes were placed on ice for a minimum of $10 \mathrm{~min}$, followed by vortexing to dislodge the adherent trophozoites from the walls of the culture vessel. The suspensions were mounted onto a Neubauer haemocytometer (Weber, $\mathrm{UK}$ ) and the total trophozoites per $\mathrm{mL}$ were determined. The antiproliferative activity of the test extracts was determined and expressed as a $\%$ of the untreated control trophozoites per $\mathrm{mL}$.

\section{Determination of $\mathrm{IC}_{50}$ values against Giardial trophozoites}

For $\mathrm{IC}_{50}$ determinations, the plant extracts were tested by the direct enumeration method across a range of concentrations. The assays were performed as outlined above and graphs of the zone of inhibition versus concentration were plotted for each extract. Linear regression was used to calculate the $\mathrm{IC}_{50}$ values.

\section{Screen for anti-cancer bioactivity}

\section{Cancer cell lines}

The Caco-2 and HeLa carcinoma cell lines used in this study were obtained from American Type Culture Collection (Rockville, USA). The cells were cultured in Roswell Park Memorial Institute (RPMI) 1640 medium (Life Technologies), supplemented with 20mM HEPES, 10mM sodium bicarbonate, $50 \mu \mathrm{g} / \mathrm{mL}$ streptomycin, $50 \mathrm{IU} / \mathrm{mL}$ penicillin, $2 \mathrm{mM}$ glutamine and $10 \%$ foetal calf serum (Life Technologies). The cells were maintained as monolayers in $75 \mathrm{~mL}$ flasks at $37^{\circ} \mathrm{C}, 5 \% \mathrm{CO}_{2}$ in a humidified atmosphere until approximately $80 \%$ confluent.

\section{Evaluation of cancer cell anti-proliferative activity}

Evaluation of the anti-proliferative activity of the K. senegalensis extracts was as previously described ${ }^{35,36}$ Briefly, $1 \mathrm{~mL}$ of trypsin (Sigma) was added to the culture flasks and incubated at $37^{\circ} \mathrm{C}, 5 \% \mathrm{CO}_{2}$ for $15 \mathrm{~min}$ to dislodge the cancer cells. The cell suspensions were then transferred to a $10 \mathrm{~mL}$ centrifuge tube and sedimented by centrifugation. The supernatant was discarded and the cells were resuspended in $9 \mathrm{~mL}$ of fresh media. Aliquots of the resuspended cells $(70 \mu \mathrm{L}$, containing approximately 5000 cells) were added to the wells of a 96 well plate. A volume of $30 \mu \mathrm{L}$ of the test extracts or cell media (for the negative control) was added to individual wells and the plates were incubated at $37^{\circ} \mathrm{C}, 5 \% \mathrm{CO}_{2}$ for 12 hours in a humidified atmosphere. A volume of $20 \mu \mathrm{L}$ of Cell Titre 96 Aqueous One solution (Promega) was subsequently added to each well and the plates were incubated for a further 3 hours. Absorbances were recorded at 490nm using a Molecular Devices, Spectra Max M3 plate reader. All tests were performed in at least triplicate and triplicate controls were included on each plate. The anti-proliferative activity of each test was calculated as a percentage of the negative control using the following formula:

Proliferation (\% untreated control $)=\left(\mathrm{A}_{\mathrm{ct}} / \mathrm{A}_{\mathrm{cc}}\right) \times 100$

$\mathrm{A}_{\mathrm{ct}}$ is the corrected absorbance for the test extract (calculated by subtracting the absorbance of the test extract in media without cells from the extract cell test combination) and $\mathrm{A}_{\mathrm{cc}}$ is the corrected untreated control (calculated by subtracting the absorbance of the untreated control in media without cells from the untreated cell media combination).

\section{Determination of $\mathrm{IC}_{50}$ values against Caco-2 and HeLa carcinoma cells}

For $\mathrm{IC}_{50}$ determinations, the plant extracts were tested by the Cell Titre 96 colourimetric method across a range of concentrations. The assays were performed as outlined above and graphs of the zone of inhibition versus concentration were plotted for each extract. Linear regression was used to calculate the $\mathrm{IC}_{50}$ values.

\section{Toxicity screening}

\section{Reference toxins for biological screening}

Potassium dichromate $\left(\mathrm{K}_{2} \mathrm{Cr}_{2} \mathrm{O}_{7}\right)$ (AR grade, Chem-Supply, Australia) was prepared as a $2 \mathrm{mg} / \mathrm{mL}$ solution in distilled water and was serially diluted in synthetic seawater for use in the A. franciscana nauplii bioassay.

\section{Artemia franciscana nauplii toxicity screening}

Toxicity was tested using a modified Artemia franciscana nauplii lethality assay. ${ }^{37-39}$ Briefly, A. franciscana cysts were obtained from North American Brine Shrimp, LLC, USA (harvested from the Great Salt Lake, Utah). Synthetic seawater was prepared using Reef Salt, AZOO Co., USA. Seawater solutions at $34 \mathrm{~g} / \mathrm{L}$ distilled water were prepared prior to use. An amount of $1 \mathrm{~g}$ of $A$. franciscana cysts were incubated in $500 \mathrm{~mL}$ synthetic seawater under artificial light at $25^{\circ} \mathrm{C}, 2000$ Lux with continuous aeration. Hatching commenced within $16-18 \mathrm{~h}$ of incubation. Newly hatched A. franciscana (nauplii) were used within $10 \mathrm{~h}$ of hatching. Nauplii were separated from the shells and remaining cysts and were concentrated to a suitable density by placing an artificial light at one end of their incubation vessel and the nauplii rich water closest to the light was removed for biological assays. The extracts and positive control were also serially diluted in artificial seawater for $\mathrm{LC}_{50}$ determination. A volume of $400 \mu \mathrm{L}$ of seawater containing approximately 52 (mean 51.8, $\mathrm{n}=125, \mathrm{SD} 11.7$ ) nauplii were added to wells of a 48 well plate and immediately used for bioassay. The plant extracts were diluted to $4 \mathrm{mg} / \mathrm{mL}$ in seawater for toxicity testing, resulting in a $2 \mathrm{mg} / \mathrm{mL}$ concentration in the bioassay. Volumes of $400 \mu \mathrm{L}$ of diluted plant extract and the reference toxins were transferred to individual wells and incubated at $25 \pm 1^{\circ} \mathrm{C}$ under artificial light (1000 
Lux). A negative control ( $400 \mu \mathrm{L}$ seawater) was run in at least triplicate for each plate. All treatments were performed in at least triplicate. The wells were checked at regular intervals and the number of dead counted. The nauplii were considered dead if no movement of the appendages was observed within $10 \mathrm{sec}$. After $48 \mathrm{~h}$ all nauplii were sacrificed and counted to determine the total number per well. The $\mathrm{LC}_{50}$ with $95 \%$ confidence limits for each treatment was calculated using probit analysis.

\section{Non-targeted GC-MS head space analysis}

Separation and quantification of phytochemical components were performed using a Shimadzu GC-2010 plus (USA) linked to a Shimadzu MS TQ8040 (USA) mass selective detector system as previously described. ${ }^{40}$ Briefly, the system was equipped with a Shimadzu auto-sampler AOC5000 plus (USA) fitted with a solid phase micro-extraction fibre (SPME) handling system utilising a Supelco (USA) divinyl benzene/carbowax/ polydimethylsiloxane (DVB/CAR/PDMS). Chromatographic separation was accomplished using a 5\% phenyl, 95\% dimethylpolysiloxane (30m x $0.25 \mathrm{~mm}$ id x 0.25um) capillary column (Restek USA). Helium (99.999\%) was employed as a carrier gas at a flow rate of $0.79 \mathrm{~mL} / \mathrm{min}$. The injec- tor temperature was set at $230^{\circ} \mathrm{C}$. Sampling utilised a SPME cycle which consisted of an agitation phase at $500 \mathrm{rpm}$ for a period of $5 \mathrm{sec}$. The fibre was exposed to the sample for $10 \mathrm{~min}$ to allow for absorption and then desorbed in the injection port for $1 \mathrm{~min}$ at $250^{\circ} \mathrm{C}$. The initial column temperature was held at $30^{\circ} \mathrm{C}$ for $2 \mathrm{~min}$, increased to $140^{\circ} \mathrm{C}$ for $5 \mathrm{~min}$, then increased to $270^{\circ} \mathrm{C}$ over a period of $3 \mathrm{mins}$ and held at that temperature for the duration of the analysis. The GC-MS interface was maintained at $200^{\circ} \mathrm{C}$ with no signal acquired for a min after injection in split-less mode. The mass spectrometer was operated in the electron ionisation mode at $70 \mathrm{eV}$. The analytes were then recorded in total ion count (TIC) mode. The TIC was acquired after a min and for duration of $45 \mathrm{mins}$ utilising a mass range of $45-450 \mathrm{~m} / \mathrm{z}$.

\section{Statistical analysis}

Data are expressed as the mean \pm SEM of at least three independent experiments. One way ANOVA was used to calculate statistical significance between control and treated groups with a $\mathrm{P}$ value $<0.01$ considered to be statistically significant.

Table 1: Therapeutic uses, selected disease models and the drug targets that $K$. senegalensis extracts have been studied against.

\begin{tabular}{|c|c|c|c|c|}
\hline $\begin{array}{l}\text { Therapeutic Use/ } \\
\text { Disease }\end{array}$ & Target/Test System & Plant Product Tested & Comments/Phytocompounds/Mechanisms & References \\
\hline $\begin{array}{l}\text { Chronic oxidative } \\
\text { disease }\end{array}$ & DPPH free radical scavenging activity & Stem bark solvent extractions & Bioactive components were not determined. & [6] \\
\hline Fungal pathogens & Botrytis cinerea & $\begin{array}{l}\text { K. senegalensis fruit extracts } \\
\text { and isolated compounds }\end{array}$ & $\begin{array}{l}\text { Multiple bioactive limonoids including several } \\
\text { seneganolides. }\end{array}$ & [7] \\
\hline $\begin{array}{l}\text { Insect deterrant/ } \\
\text { antifeedant } \\
\text { properties }\end{array}$ & $\begin{array}{c}\text { Spodoptera littoralis (African cotton } \\
\text { leafworm) larvae }\end{array}$ & $\begin{array}{l}\text { Stem bark extracts and } \\
\text { isolated compounds }\end{array}$ & $\begin{array}{l}\text { Khayanolides A, B and C, other limonoids, } \\
\text { angolensates and triterpenoids. }\end{array}$ & [8] \\
\hline Diarrhoea, dysentry & $\begin{array}{l}\text { A broad panel of bacterial species } \\
\text { associated with food poisoning, } \\
\text { diarrhoea and dysentery. }\end{array}$ & $\begin{array}{l}\text { Leaf and bark solvent } \\
\text { extractions }\end{array}$ & Flavonoids, terpenoids, tannins, saponins & {$[9,10]$} \\
\hline Antiseptic & $\begin{array}{l}\text { Staphylococcus aureus, Streptococcus } \\
\text { spp., E. coli, P. aeruginosa, } \\
\text { Salmmonella spp., B. cereus }\end{array}$ & $\begin{array}{l}\text { Root, stem bark and leaf } \\
\text { extracts }\end{array}$ & $\begin{array}{l}\text { Polyphenolic compounds, flavonoids, saponins, } \\
\text { terpenoids }\end{array}$ & {$[9,10]$} \\
\hline Immunostimulation & Macrophages & $\begin{array}{l}\text { Solvent extractions and } \\
\text { isolated compounds }\end{array}$ & $\begin{array}{l}\text { Dimeric proanthocyanidins induce TNF- } \alpha \\
\text { secretion from macrophages }\end{array}$ & [11] \\
\hline Inflammation & $\begin{array}{l}\text { HCT-15, HT-29 and HCA-7 } \\
\text { colorectal cancer cells }\end{array}$ & Stem bark solvent extractions & $\begin{array}{l}\text { Bioactive components were not determined. } \\
\text { COX-2 dependent and independent anti- } \\
\text { inflammatory mechanisms were reported. }\end{array}$ & [6] \\
\hline Diabetes & Wistar rats & Aqueous stem bark extract & $\begin{array}{l}\text { Anti-hyperglycemic activity comparable to } \\
\text { glibenclamide was reported. }\end{array}$ & {$[12]$} \\
\hline Cancer & $\begin{array}{c}\text { MCF-7 (breast cancer), SiHa (cervical } \\
\text { cancer and Caco-2 (colorectal) cancer } \\
\text { cell lines. }\end{array}$ & Stem bark solvent extractions & Limonoids & [13] \\
\hline Colorectal cancer & $\begin{array}{l}\text { HCT-15, HT-29 and HCA-7 } \\
\text { colorectal cancer cells }\end{array}$ & Stem bark solvent extractions & $\begin{array}{l}\text { Anti-proliferative and pro-apoptotic activities } \\
\text { were reported against all cell lines. }\end{array}$ & {$[6,14]$} \\
\hline Malaria & $\begin{array}{l}\text { Chloroquine resistant and } \\
\text { chloroquine sensitive Plasmodium } \\
\text { falciparum strains }\end{array}$ & $\begin{array}{l}\text { Leaf, seed and stem bark } \\
\text { solvent extracts. }\end{array}$ & $\begin{array}{l}\text { Terpenoids. The bark extract was particularly } \\
\text { potent }\left(\mathrm{IC}_{50}=3 \mu \mathrm{M}\right)\end{array}$ & [15] \\
\hline $\begin{array}{l}\text { Trypanosomiasis: } \\
\text { Surra }\end{array}$ & Trypanosoma evansi & $\begin{array}{l}\text { Stem bark, root bark and leaf } \\
\text { extracts }\end{array}$ & $\begin{array}{l}\text { Phytochemistry was not studied, although } \\
\text { the authors postulated that flavonoids may } \\
\text { contribute to the activity. }\end{array}$ & {$[16]$} \\
\hline $\begin{array}{l}\text { Trypanosomiasis: } \\
\text { Sleeping sickness }\end{array}$ & Trypanosoma brucei & Stem bark extract. & $\begin{array}{c}\text { Inhibits T. brucei proliferation in vivo via } \\
\text { changes in levels of aspartate and alanine } \\
\text { transaminases. }\end{array}$ & {$[16]$} \\
\hline Leishmaniasis & $\begin{array}{l}\text { Leishmania donovani, L. infatum, } L . \\
\text { enriettii and L. major }\end{array}$ & $\begin{array}{l}\text { Solvent extractions and } \\
\text { isolated compounds }\end{array}$ & $\begin{array}{l}\text { Dimeric proanthocyanidins were implicated via } \\
\text { immunostimulation. }\end{array}$ & [11] \\
\hline
\end{tabular}




\section{RESULTS}

\section{Liquid extraction yields and qualitative phytochemical screening}

Extraction of $1 \mathrm{~g}$ of dried plant material with various solvents yielded dried plant extracts ranging from approximately $47 \mathrm{mg}$ to $233 \mathrm{mg}$ (Table 2 ). The methanol and the SFE extracts had the highest yields of dried extracted material (233 and $188 \mathrm{mg}$, respectively). Water, ethyl acetate, chloroform and hexane extracted lower masses (approximately 130, 47, 63 , and $57 \mathrm{mg}$, respectively). The dried extracts were resuspended in $10 \mathrm{~mL}$ of deionised water (containing $1 \%$ DMSO) resulting in the extract concentrations shown in Table 2. Phytochemical studies (Table 2) showed that the methanol, water and the SFE extracts contained the widest range and largest amount of phytochemicals in this study. Each of these contained high levels of total phenolics and moderate to high levels of saponins, triterpenoids and tannins. Similar classes of phytochemicals were detected in the ethyl acetate, chloroform and hexane extracts, albeit generally at lower levels.

\section{Antimicrobial activity}

Aliquots $(10 \mu \mathrm{L})$ of each extract were tested in the disc diffusion assay against bacterial species associated with the induction of rheumatoid arthritis (Proteus mirabilis, Figure 2a; Proteus vulgaris, Figure 2b), ankylosing spondylitis (Klebsiella pneumoniae, Figure 3), multiple sclerosis (Acinitobacter baylyi, Figure 4a; Pseudomonas aeruginosa, Figure 4b) and rheumatic fever (Streptococcus pyogenes, Figure 5). The K. senegalensis bark extracts were potent inhibitors of reference and clinical strains of P. mirabilis (Figure 2a), with zones of inhibition up to approximately $15 \mathrm{~mm}$. The methanolic extract was particularly potent, with inhibition zones of $13.0 \pm 1.0$ and $14.7 \pm 1.2 \mathrm{~mm}$ against the reference and clinical strains, respectively. The aqueous $(9.6 \pm 0.6$ and $8.8 \pm 0.4 \mathrm{~mm}$ for the reference and clinical strains respectively) and ethyl acetate $(8.9 \pm 0.6$ and $7.3 \pm 0.3 \mathrm{~mm}$ for the reference and clinical strains, respectively) were also good inhibitors of $P$. mirabilis growth. The hexane extract also inhibited $P$. mirabilis growth, although lower efficacy $(7.3 \pm 0.3 \mathrm{~mm}$ and 6.7 $\pm 0.3 \mathrm{~mm}$ for the reference and clinical strains, respectively) was evident than for the methanolic, aqueous and ethyl acetate extracts. In contrast, the chloroform extract was completely devoid of $P$. mirabilis growth inhibitory activity. The K. senegalensis bark extracts were similarly potent growth inhibitors against $P$. vulgaris (Figure 2b). A zone of inhibition of $9.7 \pm 0.6 \mathrm{~mm}$ was recorded for the methanolic extract. Similarly, growth inhibition zones of $7.5 \pm 0.5$ and $6.7 \pm 0.3 \mathrm{~mm}$ were seen for the aqueous and ethyl acetate extracts, respectively. In contrast, both the chloroform and hexane extracts were completely devoid of $P$. vulgaris growth inhibitory activity.

The subcritical $K$. senegalensis bark extract was also a good inhibitor of Proteus spp. growth. It was a particularly potent inhibitor of $P$. vulgaris growth $(9.3 \pm 0.6 \mathrm{~mm}$; Figure $2 \mathrm{~b})$. Similarly, although slightly lower growth inhibitory potency was noted against $P$. mirabilis, with zones of inhibition of $8.3 \pm 0.3$ and $8.0 \mathrm{~mm}$ against $P$. mirabilis (reference and clinical strains, respectively). The subcritical extract displayed slightly lower efficacy to the small scale laboratory extraction (as judged by zone of inhibition). As Proteus spp. (particularly P. mirabilis) are triggers of rheumatoid arthritis in genetically susceptible people,$^{41,42}$ these extracts may be useful in the prevention and treatment of this disease.

A similar activity profile was evident for K. pneumoniae growth inhibition (Figure 3). The methanolic extract was the most potent growth inhibitor, with zones of inhibition of $9.3 \pm 0.3 \mathrm{~mm}$ (reference strain) and $8.6 \pm 0.3 \mathrm{~mm}$ (clinical strain). This compares favourably with the ampicillin control $(10 \mu \mathrm{g})$ which had $9.2 \pm 0.4$ (reference strain) and $8.7 \pm$ $0.3 \mathrm{~mm}$ (clinical strain) zones of inhibition. The aqueous, ethyl acetate chloroform, hexane and subcritical extracts also inhibited K. pneumoniae growth, albeit with lower efficacy ( 6.7 to $7.5 \mathrm{~mm}$ zones of inhibition). As K. pneumoniae can trigger ankylosing spondylitis in genetically susceptible individuals ${ }^{43}$ these extracts have potential in the prevention and treatment of this disease.

The K. senegalensis bark extracts were also screened for growth inhibitory activity against bacterial triggers of multiple sclerosis (Acinitobacter baylyi, Figure 4a; Pseudomonas aeruginosa, Figure $4 \mathrm{~b}),{ }^{44,45}$ The ethyl acetate extract was the most potent $A$. baylyi growth inhibitor, with zones

Table 2: The mass of dried extracted material, the concentration after resuspension in deionised water and qualitative phytochemical screenings of the $K$. senegalensis bark extracts.

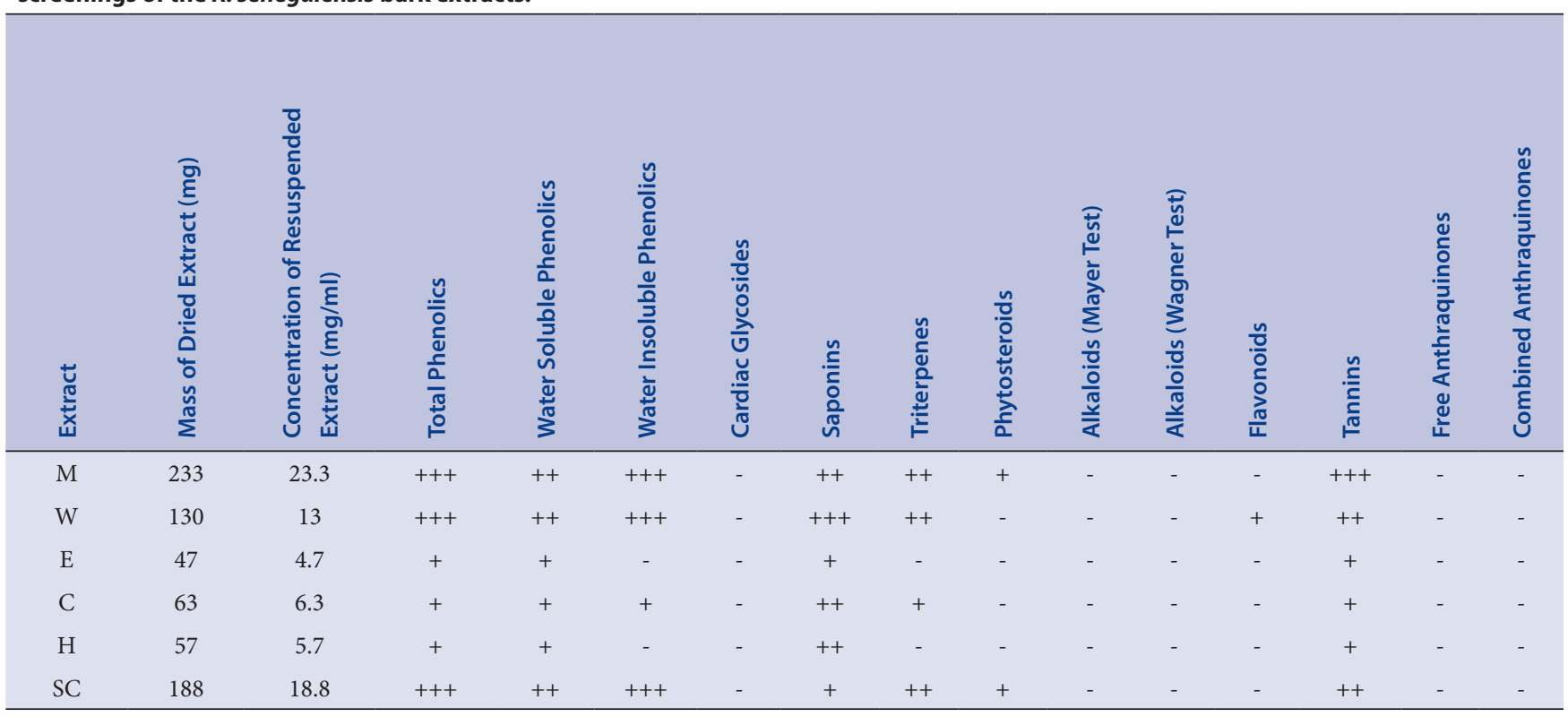

+++ indicates a large response; ++ indicates a moderate response; + indicates a minor response; - indicates no response in the assay. $\mathrm{M}=$ methanolic extract; $\mathrm{W}=$ aqueous extract; $\mathrm{E}=$ ethyl acetate extract; $\mathrm{C}=$ chloroform extract; $\mathrm{H}=$ hexane extract; $\mathrm{SC}=$ subcritical extract. 


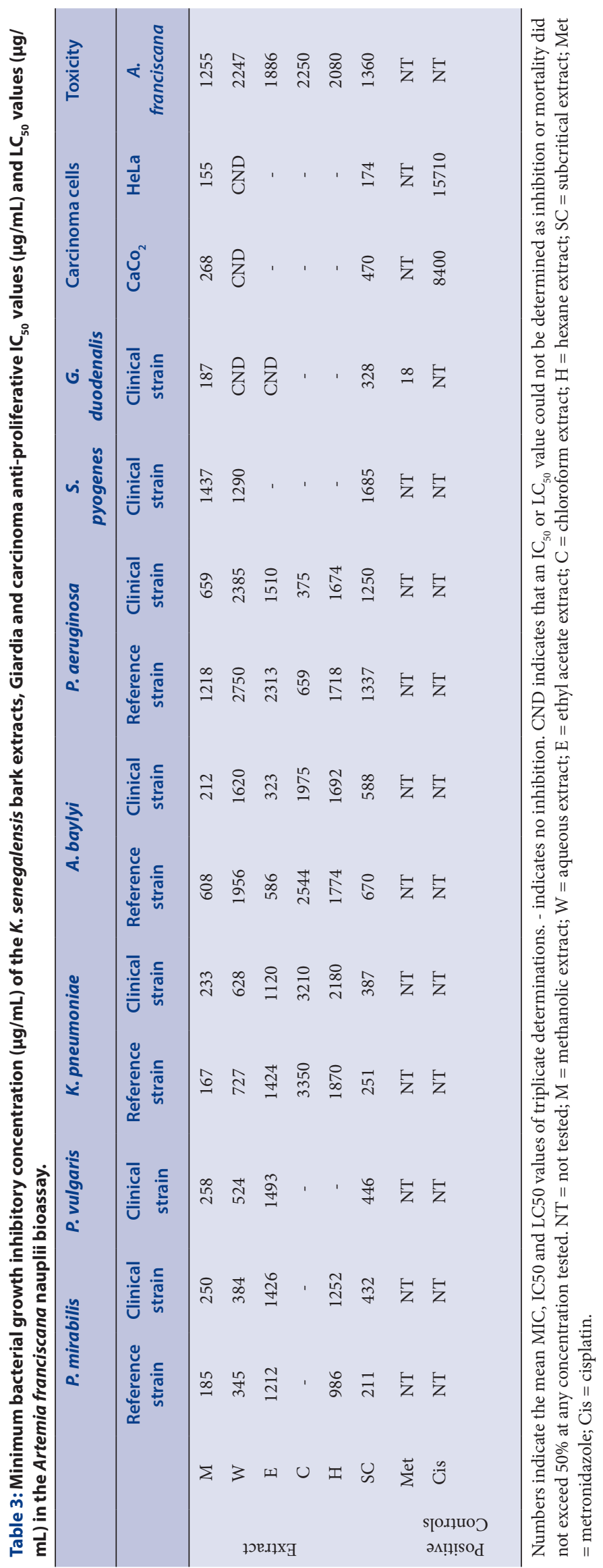

of inhibition of $12.0 \pm 1.0$ and $15.7 \pm 1.3 \mathrm{~mm}$ against the reference and clinical isolate strains, respectively. Potent growth inhibition was also determined for the methanolic extract $(9.0 \pm 1.0$ and $10.7 \pm 1.2 \mathrm{~mm}$ for the reference and clinical isolate strains, respectively), hexane ( $8.3 \pm 0.3$ and $9.0 \mathrm{~mm}$ for the reference and clinical isolate strains, respectively) and SFE extracts $(9.5 \pm 0.5$ and $10.0 \pm 1.0 \mathrm{~mm}$ for the reference and clinical isolate strains, respectively). These results compare favourably to the ampicillin control ( $8.6 \pm 0.3 \mathrm{~mm}$ zones of inhibition against both A. baylyi strains). Although smaller inhibition zones (generally $7-8 \mathrm{~mm}$ ) were measured for the aqueous and chloroform extracts, these extracts were still deemed to be good $A$. baylyi growth inhibitors.

The methanolic (zones of inhibition of $14.6 \pm 1.3$ and $17.3 \pm 1.2 \mathrm{~mm}$ against the reference and clinical isolate strains, respectively) and chloroform K. senegalensis extracts (zones of inhibition of $12.0 \pm 1.0$ and $18.0 \pm 1.0 \mathrm{~mm}$ against the reference and clinical isolate strains, respectively) were also potent inhibitors of $P$. aeruginosa growth (Figure $4 \mathrm{~b}$ ). The ethyl acetate extract was a similarly potent growth inhibitor against the clinical strain $(10.3 \pm 0.6 \mathrm{~mm})$. However, it was a substantially less potent against the reference strain $(8.3 \pm 0.3 \mathrm{~mm})$, although these results are still indicative of strong growth inhibition. Whilst less potent, the aqueous, hexane and SFE extracts were also good $P$. aeruginosa growth inhibitors, with zones of inhibition generally $6.7-8.3 \mathrm{~mm}$. The $P$. aeruginosa growth inhibition was particularly noteworthy as both the reference and clinical $P$. aeruginosa strains are antibiotic resistant strains. Indeed, the $10 \mu \mathrm{g}$ ampicillin control used in our studies only produced $6.2 \pm 0.4$ and $5.5 \pm 0.3 \mathrm{~mm}$ zones of inhibition for the reference and clinical strains, respectively. This finding is supported by previous studies which have also reported these strains to be antibiotic resistant. ${ }^{24,47}$ Thus, the K. senegalensis extracts are particularly potent growth inhibitors and may be useful for the inhibition of $P$. aeruginosa growth. Therefore, as both $A$. baylyi and $P$. aeruginosa can trigger multiple sclerosis in genetically susceptible individuals, ${ }^{44}$ these extracts have potential in the prevention and treatment of this disease.

The K. senegalensis methanolic, aqueous and SFE extracts also inhibited Streptococcus pyogenes growth (Figure 5), albeit with zones of inhibition that indicate only moderate inhibitory activity. The aqueous leaf extract was the most potent growth inhibitor, with an inhibition zone of $7.3 \pm$ $0.3 \mathrm{~mm}$, whilst both the methanolic and subcritical extracts gave inhibition zones substantially $<7 \mathrm{~mm}$. However, this would be considered to be only moderate inhibition and is substantially less potent than the ampicillin control ( $8.3 \pm 0.3 \mathrm{~mm}$ zones of inhibition). In contrast, the ethyl acetate, chloroform and hexane extracts were completely devoid of inhibitory activity. $S$. pyogenes has been implicated in a number of diseases including rheumatic fever. Thus, the $K$. senegalensis methanolic, aqueous and subcritical extracts have some potential in the prevention and treatment of these diseases.

The relative level of antimicrobial activity was further evaluated by determining the MIC values (Table 3) for each extract against the bacterial species which were shown to be susceptible by disc diffusion assays. Most of the extracts were effective at inhibiting microbial growth at low concentrations, with many MIC values against the bacterial species that they inhibited generally $<1000 \mu \mathrm{g} / \mathrm{mL}(<10 \mu \mathrm{g}$ impregnated in the disc), indicating the potent antimicrobial activity of these extracts. These MIC values compare favourably with the dosages of the pure standard ampicillin which was tested using $10 \mu \mathrm{g}$ per disc. The methanol, water and SFE extracts were particularly potent with MIC values in the range 160$500 \mu \mathrm{g} / \mathrm{ml}$ against several species. Indeed, MIC values of $185 \mu \mathrm{g} / \mathrm{mL}$ (approximately $1.9 \mathrm{mg}$ in the disc; $P$. mirabilis reference strain), $167 \mu \mathrm{g} / \mathrm{mL}$ (approximately $1.7 \mathrm{mg}$ in the disc; K. pneumoniae reference strain) and $212 \mu \mathrm{g} / \mathrm{mL}$ (approximately $2.2 \mathrm{mg}$ in the disc; A. baylyi clinical strain), were determined for the methanolic extract. Similarly potencies were 
evident for the aqueous and SFE extracts. Whilst the ethyl acetate, chloroform and hexane extracts also had broad spectrum inhibitory activity against many of the bacterial species, they generally had much lower efficacies (with some MIC values $>2000 \mu \mathrm{g} / \mathrm{ml}$ ).

\section{Anti-Giardial activity}

K. senegalensis bark extracts were screened for their ability to inhibit Giardia duodenalis growth (Figure 6). The methanol, water, ethyl acetate and SFE extracts displayed significant inhibitory activity. The methanolic
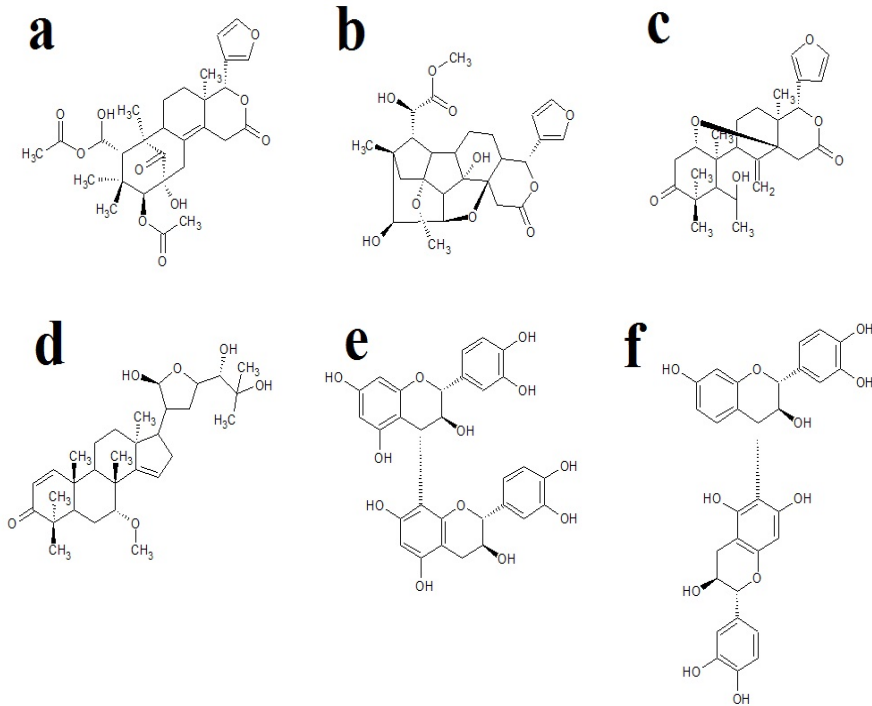

Figure 1: Chemical structures of selected molecules identified $K$. senegalensis extracts: (a) a characteristic limonoid structure (2-hydroxyseneganolide $A$ is depicted), (b) a characteristic khayanolide structure (1-O-acetylkhayanolide B is depicted), (c) 6-hydroxy-methyl angolensate, (d) a characteristic senegalene triterpenoid structure (senegalene $C$ is depicted), (e) proanthocyanidin B3, (f) fisetinidol-(4a, 6)-catechin.

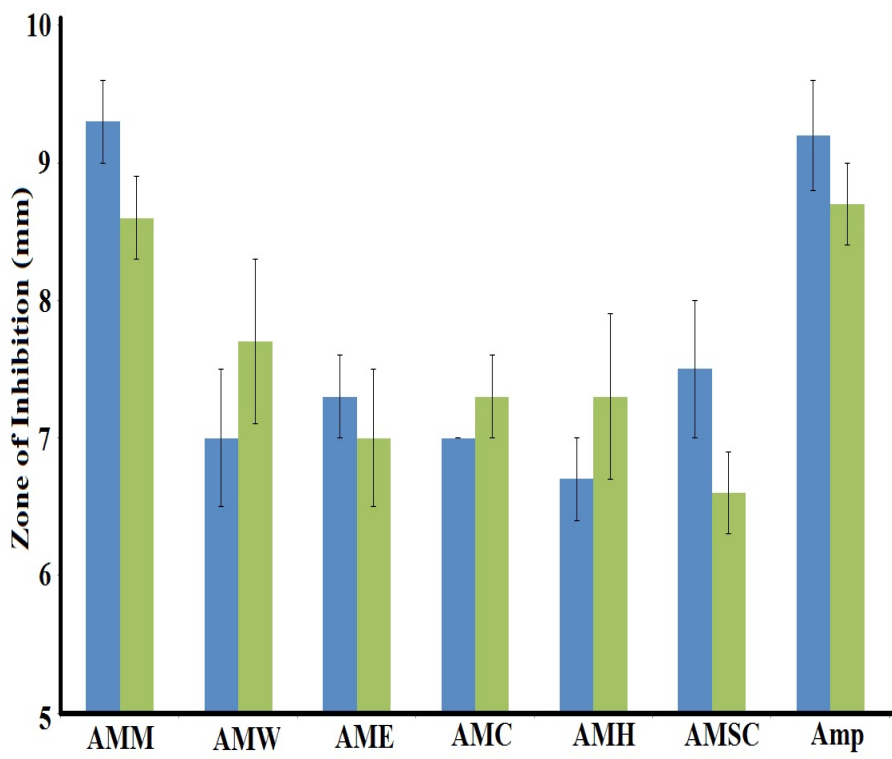

Figure 3: Antibacterial activity of $K$. senegalensis extracts measured as zones of inhibition $(\mathrm{mm})$ against a bacterial trigger of ankylosing spondylitis (Klebsiella pneumoniae). Results are expressed as mean \pm SEM of at least triplicate determinations. Blue bars represent inhibition of the reference bacterial strain. Green bars represent inhibition of the clinical bacterial strain. AMM = methanolic extract; $\mathrm{AMW}=$ aqueous extract; $\mathrm{AME}=$ ethyl acetate extract; $\mathrm{AMC}=$ chloroform extract; $\mathrm{AMH}=$ hexane extract; $\mathrm{AMSC}=\mathrm{SFE}$ extract; $\mathrm{Amp}$ $=$ ampicillin control $(10 \mu \mathrm{g})$. and SFE extracts were particularly potent, inhibiting $95 \%$ and $100 \%$ of the Giardial growth, respectively (compared to the untreated control). The chloroform and hexane extracts were ineffective as proliferation inhibitors, with no significant difference to the untreated control levels.

The $K$. senegalensis extracts were further tested over a range of concentrations to determine the $\mathrm{IC}_{50}$ values (Table 3 ) for each extract against $G$. duodenalis. Inhibition of trophozoite growth was dose-dependent, with the level of inhibitory activity decreasing at lower concentrations. The

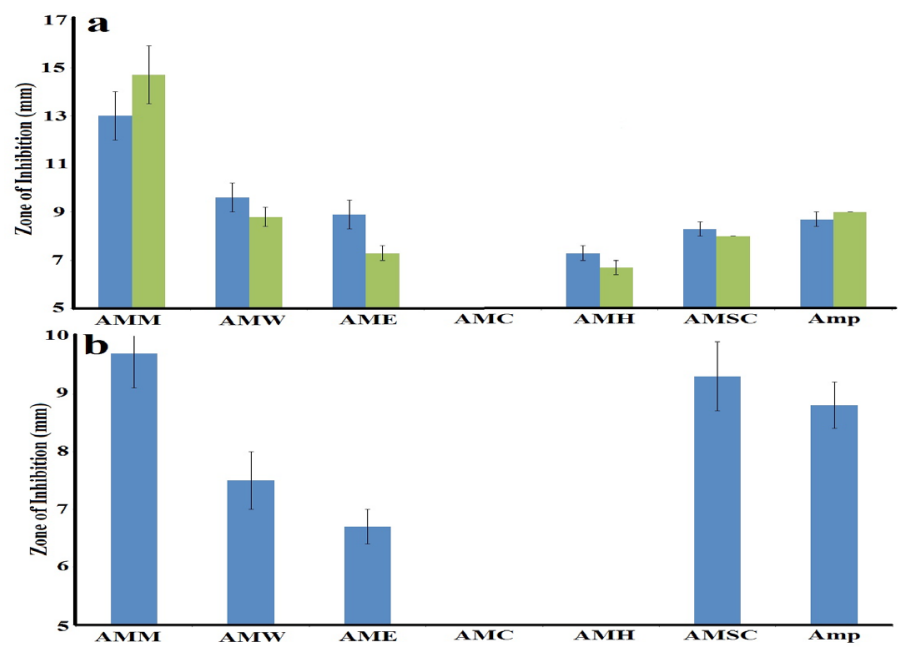

Figure 2: Antibacterial activity of the $K$. senegalensis extracts measured as zones of inhibition $(\mathrm{mm})$ against bacterial triggers of rheumatoid arthritis: (a) Proteus mirabilis, (b) Proteus vulgaris. Results are expressed as mean \pm SEM of at least triplicate determinations. Blue bars represent inhibition of the reference bacterial strain. Green bars represent inhibition of the clinical bacterial strain. $\mathrm{AMM}=$ methanolic extract; $\mathrm{AMW}=$ aqueous extract; $\mathrm{AME}=$ ethyl acetate extract; $\mathrm{AMC}=$ chloroform extract; $\mathrm{AMH}=$ hexane extract; $\mathrm{AMSC}=$ SFE extract; Amp = ampicillin control (10 $\mu \mathrm{g})$.
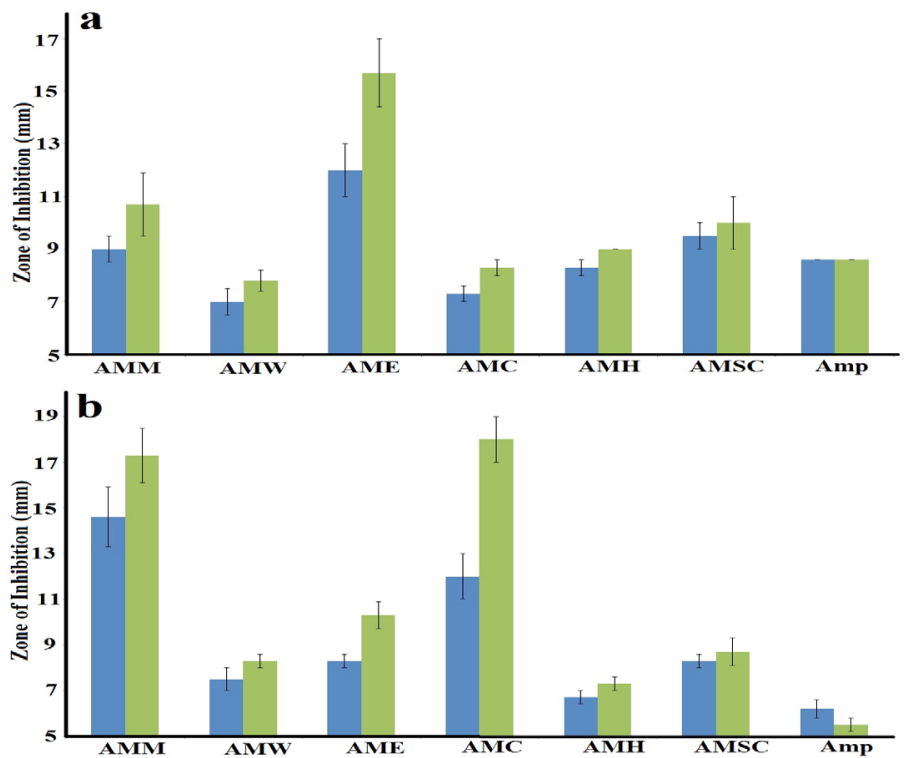

Figure 4: Antibacterial activity of $K$. senegalensis extracts measured as zones of inhibition $(\mathrm{mm}$ ) against a bacterial trigger of multiple sclerosis: (a) Acinito bacter baylyi, (b) Pseudomonas aeruginosa. Results are expressed as mean \pm SEM of at least triplicate determinations. Blue bars represent inhibition of the reference bacterial strain. Green bars represent inhibition of the clinical bacterial strain. $\mathrm{AMM}=$ methanolic extract; $\mathrm{AMW}=$ aqueous extract; $\mathrm{AME}=$ ethyl acetate extract; $\mathrm{AMC}=$ chloroform extract; $\mathrm{AMH}=$ hexane extract; $\mathrm{AMSC}=$ SFE extract; $A m p=$ ampicillin control $(10 \mu \mathrm{g})$. 
Table 4: Qualitative headspace GC-MS analysis of the SFE K. senegalensis bark extract, elucidation of empirical formulas and putative identification (where possible) of the compounds.

\begin{tabular}{|c|c|c|c|c|}
\hline $\begin{array}{l}\text { Retention Time } \\
\quad(\mathrm{min})\end{array}$ & Molecular Mass & Empirical Formula & Area (\%) & Putative Identification \\
\hline 10.54 & 151 & $\mathrm{C}_{8} \mathrm{H}_{9} \mathrm{NO}_{2}$ & 0.17 & Oxime-, methoxy-phenyl- \\
\hline 10.825 & 130 & $\mathrm{C}_{7} \mathrm{H}_{14} \mathrm{O}_{2}$ & 0.19 & Hexanoic acid, methyl ester \\
\hline 10.99 & 178 & $\mathrm{C}_{8} \mathrm{H}_{18} \mathrm{O}_{4}$ & 0.23 & 2,5-Dimethylhexane-2,5-dihydroperoxide \\
\hline 11.125 & 122 & $\mathrm{C}_{8} \mathrm{H}_{10} \mathrm{O}$ & 0.15 & Oxepine, 2,7-dimethyl- \\
\hline 11.385 & 128 & $\mathrm{C}_{8} \mathrm{H}_{16} \mathrm{O}$ & 0.36 & 2-Heptanone, 4-methyl- \\
\hline 11.695 & 100 & $\mathrm{C}_{6} \mathrm{H}_{12} \mathrm{O}$ & 0.06 & Furan, tetrahydro-2,5-dimethyl- \\
\hline 11.935 & & & 0.22 & \\
\hline 12.425 & 144 & $\mathrm{C}_{8} \mathrm{H}_{16} \mathrm{O}_{2}$ & 1.31 & Formic acid, heptyl ester \\
\hline 12.66 & 128 & $\mathrm{C}_{8} \mathrm{H}_{16} \mathrm{O}$ & 0.73 & 1-Octen-3-ol \\
\hline 12.815 & 170 & $\mathrm{C}_{10} \mathrm{H}_{18} \mathrm{O}_{2}$ & 0.69 & 2-Hydroxy-1,8-cineole \\
\hline 13.05 & 136 & $\mathrm{C}_{10} \mathrm{H}_{16}$ & 4.11 & $\beta$-Pinene \\
\hline 13.105 & & & 0.35 & \\
\hline 13.21 & & & 0.91 & \\
\hline 13.46 & & & 3.34 & \\
\hline 13.87 & 136 & $\mathrm{C}_{10} \mathrm{H}_{16}$ & 0.37 & Terpinolene \\
\hline 14.03 & 134 & $\mathrm{C}_{10} \mathrm{H}_{14}$ & 0.4 & o-Cymene \\
\hline 14.295 & 154 & $\mathrm{C}_{10} \mathrm{H}_{18} \mathrm{O}$ & 20.43 & 1,8-Cineole \\
\hline 14.48 & 136 & $\mathrm{C}_{10} \mathrm{H}_{16}$ & 0.91 & a-Pinene \\
\hline 14.875 & 136 & $\mathrm{C}_{10} \mathrm{H}_{16}$ & 1.79 & Pseudolimonene \\
\hline 15.125 & 168 & $\mathrm{C}_{19} \mathrm{H}_{16} \mathrm{O}_{2}$ & 0.74 & 2H-Pyran-2-one, tetrahydro-6-(2-penteny \\
\hline 15.215 & & & 0.06 & \\
\hline 15.33 & 156 & $\mathrm{C}_{9} \mathrm{H}_{16} \mathrm{O}_{2}$ & 0.08 & Butanoic acid, 4-pentenyl ester \\
\hline 15.675 & 242 & $\mathrm{C}_{13} \mathrm{H}_{22} \mathrm{O}_{4}$ & 4.91 & $\begin{array}{l}\text { Ethyl 2-(5-methyl-5-vinyltetrahydrofuran-2-yl)propan-2-yl } \\
\text { carbonate }\end{array}$ \\
\hline 15.66 & 120 & $\mathrm{C}_{8} \mathrm{H}_{8} \mathrm{O}$ & 0.01 & Benzaldehyde, 2-methyl- \\
\hline 15.9 & 130 & $\mathrm{C}_{7} \mathrm{H}_{14} \mathrm{O}_{2}$ & 0.66 & Heptanoic acid \\
\hline 16.05 & 170 & $\mathrm{C}_{10} \mathrm{H}_{18} \mathrm{O}_{2}$ & 3.2 & Linalool oxide \\
\hline 16.16 & 136 & $\mathrm{C}_{7} \mathrm{H}_{8} \mathrm{~N}_{2} \mathrm{O}$ & 0.49 & Benzoic acid, hydrazide \\
\hline 16.635 & 154 & $\mathrm{C}_{10} \mathrm{H}_{18} \mathrm{O}$ & 30.34 & Linalool \\
\hline 16.83 & & & 0.39 & \\
\hline 17.325 & 136 & $\mathrm{C}_{10} \mathrm{H}_{16}$ & 0.4 & 2,4,6-Octatriene, 2,6-dimethyl-, (E,E)- \\
\hline 17.475 & 168 & $\mathrm{C}_{11} \mathrm{H}_{20} \mathrm{O}$ & 0.28 & Linalool, methyl ether \\
\hline 17.575 & 152 & $\mathrm{C}_{10} \mathrm{H}_{16} \mathrm{O}$ & 0.33 & Pinocarveol \\
\hline 17.72 & & & 0.42 & \\
\hline 17.875 & 128 & $\mathrm{C}_{7} \mathrm{H}_{12} \mathrm{O}_{2}$ & 0.14 & 2(3H)-Furanone, dihydro-5-propyl- \\
\hline 18.15 & & & 0.33 & \\
\hline 18.405 & 154 & $\mathrm{C}_{10} \mathrm{H}_{18} \mathrm{O}$ & 0.52 & $\delta$-Terpineol \\
\hline 18.48 & 170 & $\mathrm{C}_{10} \mathrm{H}_{18} \mathrm{O}_{2}$ & 0.19 & trans-Linalool 3,7-oxide \\
\hline 18.605 & & & 0.58 & \\
\hline 18.78 & 154 & $\mathrm{C}_{10} \mathrm{H}_{18} \mathrm{O}$ & 1.88 & 1-Terpinen-4-ol \\
\hline 19.175 & 154 & $\mathrm{C}_{10} \mathrm{H}_{18} \mathrm{O}$ & 4.25 & a-Terpineol \\
\hline 19.24 & 150 & $\mathrm{C}_{10} \mathrm{H}_{14} \mathrm{O}$ & 0.03 & $\alpha$-Thujenal \\
\hline 19.47 & 246 & $\mathrm{C}_{18} \mathrm{H}_{30}$ & 0.11 & Benzene, (2,3-dimethyldecyl)- \\
\hline 19.785 & & & 0.33 & \\
\hline 19.895 & 128 & $\mathrm{C}_{8} \mathrm{H}_{16} \mathrm{O}$ & 0.03 & 3-Heptanone, 2-methyl- \\
\hline 19.975 & 168 & $\mathrm{C}_{11} \mathrm{H}_{20} \mathrm{O}$ & 0.05 & 4-(2-Methoxypropan-2-yl)-1-methylcyclohex-1-ene \\
\hline
\end{tabular}




\begin{tabular}{|c|c|c|c|c|}
\hline 20.135 & 168 & $\mathrm{C}_{11} \mathrm{H}_{20} \mathrm{O}$ & 0.04 & 2,6-Octadiene, 1-methoxy-3,7-dimethyl-, \\
\hline 20.285 & 196 & $\mathrm{C}_{12} \mathrm{H}_{20} \mathrm{O}_{2}$ & 0.09 & 2,6-Octadien-1-ol, 3,7-dimethyl-, acetate, \\
\hline 20.445 & 152 & $\mathrm{C}_{9} \mathrm{H}_{12} \mathrm{O}_{2}$ & 0.07 & 3,4-Dimethoxytoluene \\
\hline 20.56 & 152 & $\mathrm{C}_{10} \mathrm{H}_{16} \mathrm{O}$ & 0.09 & Neral \\
\hline 20.67 & 113 & $\mathrm{C}_{6} \mathrm{H}_{11} \mathrm{NO}$ & 0.05 & Caprolactam \\
\hline 21.065 & 152 & $\mathrm{C}_{10} \mathrm{H}_{16} \mathrm{O}$ & 2.2 & Piperitone \\
\hline 21.2 & & & 0.09 & \\
\hline 21.42 & 158 & $\mathrm{C}_{9} \mathrm{H}_{18} \mathrm{O}_{2}$ & 0.51 & Pelargic acid \\
\hline 21.9 & & & 0.18 & \\
\hline 22.545 & 168 & $\mathrm{C}_{9} \mathrm{H}_{12} \mathrm{O}_{3}$ & 0.06 & Methylsyringol \\
\hline 22.78 & & & 0.14 & \\
\hline 23.41 & & & 0.09 & \\
\hline 23.52 & 154 & $\mathrm{C}_{8} \mathrm{H}_{10} \mathrm{O}_{3}$ & 0.02 & Pyrogallol 1,3-dimethyl ether \\
\hline 23.745 & 164 & $\mathrm{C}_{10} \mathrm{H}_{12} \mathrm{O}_{2}$ & 0.47 & Eugenol \\
\hline 23.83 & 142 & $\mathrm{C}_{8} \mathrm{H}_{14} \mathrm{O}_{2}$ & 0.09 & 2(3H)-Furanone, 5-butyldihydro- \\
\hline 23.925 & 284 & $\mathrm{C}_{18} \mathrm{H}_{36} \mathrm{O}_{2}$ & 0.04 & Stearic acid \\
\hline 24.245 & 216 & $\mathrm{C}_{12} \mathrm{H}_{24} \mathrm{O}_{3}$ & 0.12 & Propanoic acid, 2-methyl-, 3-hydroxy-2,2,4-trimethylpentyl ester \\
\hline 24.515 & 180 & $\mathrm{C}_{12} \mathrm{H}_{20} \mathrm{O}$ & 0.02 & -(2,6,6-Trimethyl-1-cyclohexen-1-yl)propanal \\
\hline 25.06 & 178 & $\mathrm{C}_{11} \mathrm{H}_{14} \mathrm{O}_{2}$ & 0.32 & Methyleugenol \\
\hline 25.48 & & & 0.17 & \\
\hline 26.74 & 220 & $\mathrm{C}_{15} \mathrm{H}_{24} \mathrm{O}$ & 0.09 & (+)-Cycloisolongifol-5-ol \\
\hline 26.885 & & & 0.14 & \\
\hline 28.145 & & & 0.33 & \\
\hline 28.98 & 206 & $\mathrm{C}_{14} \mathrm{H}_{22} \mathrm{O}$ & 0.59 & ,5-Di-tert-butylphenol \\
\hline 29.195 & & & 0.16 & \\
\hline 29.56 & 202 & $\mathrm{C}_{15} \mathrm{H}_{22}$ & 0.17 & (-)-Calamenene \\
\hline 29.96 & 220 & $\mathrm{C}_{15} \mathrm{H}_{25} \mathrm{O}$ & 0.13 & Italicene ether \\
\hline 30.09 & 200 & $\mathrm{C}_{15} \mathrm{H}_{20}$ & 0.05 & a.-Dehydro-ar-himachalene \\
\hline 30.27 & 200 & $\mathrm{C}_{15} \mathrm{H}_{20}$ & 0.2 & a.-Calacorene \\
\hline 30.43 & 220 & $\mathrm{C}_{15} \mathrm{H}_{24} \mathrm{O}$ & 0.25 & Longifolenaldehyde \\
\hline 30.555 & 208 & $\mathrm{C}_{12} \mathrm{H}_{16} \mathrm{O}_{3}$ & 0.08 & Elemicin \\
\hline 31.08 & 222 & $\mathrm{C}_{15} \mathrm{H}_{26} \mathrm{O}$ & 0.08 & (-)-Globulol \\
\hline 31.345 & 220 & $\mathrm{C}_{15} \mathrm{H}_{24} \mathrm{O}$ & 1.16 & (-)-Spathulenol \\
\hline 31.88 & & & 0.32 & \\
\hline 31.975 & 222 & $\mathrm{C}_{15} \mathrm{H}_{26} \mathrm{O}$ & 0.07 & Ledol \\
\hline 32.435 & 200 & $\mathrm{C}_{15} \mathrm{H}_{20}$ & 0.11 & a-Corocalene \\
\hline 32.665 & 222 & $\mathrm{C}_{15} \mathrm{H}_{26} \mathrm{O}$ & 0.11 & $\gamma$-Eudesmol \\
\hline 32.875 & 218 & $\mathrm{C}_{15} \mathrm{H}_{22} \mathrm{O}$ & 0.61 & $\begin{array}{c}\text { 2H-Cyclopropa[a]naphthalen-2-one, } 1,1 \mathrm{a}, 4,5,6,7,7 \mathrm{a}, 7 \mathrm{~b} \text {-octahydro- } \\
1,1,7,7 \mathrm{a} \text {-tetramethyl- }\end{array}$ \\
\hline 32.955 & 204 & $\mathrm{C}_{15} \mathrm{H}_{24} \mathrm{O}$ & 0.08 & Copaene \\
\hline 33.31 & & & 0.18 & \\
\hline 33.405 & 222 & $\mathrm{C}_{15} \mathrm{H}_{26} \mathrm{O}$ & 0.06 & Guai-1(10)-en-11-ol \\
\hline 33.52 & 198 & $\mathrm{C}_{15} \mathrm{H}_{18}$ & 0.13 & Cadalene \\
\hline 34.5 & 204 & $\mathrm{C}_{15} \mathrm{H}_{24}$ & 0.04 & $\gamma$-Neoclovene \\
\hline 34.82 & 238 & $\mathrm{C}_{15} \mathrm{H}_{26} \mathrm{O}_{2}$ & 0.16 & Isocalamenediol \\
\hline 35.06 & 218 & $\mathrm{C}_{15} \mathrm{H}_{22} \mathrm{O}$ & 0.61 & Cyperenone \\
\hline 36.505 & 278 & $\mathrm{C}_{16} \mathrm{H}_{22} \mathrm{O}_{4}$ & 0.09 & Phthalic acid, diisobutyl ester \\
\hline 37.675 & 278 & $\mathrm{C}_{16} \mathrm{H}_{22} \mathrm{O}_{4}$ & 0.01 & Dibutyl phthalate \\
\hline
\end{tabular}

The $\%$ area is expressed as a $\%$ of the total area under all chromatographic peaks. 
methanolic extract and the SFE extract were the most potent anti-proliferative agents, with $\mathrm{IC}_{50}$ values of 184 and $328 \mu \mathrm{g} / \mathrm{mL}$ respectively. Whilst the aqueous and ethyl acetate extracts inhibited G. duodenalis proliferation, we were unable to determine $\mathrm{IC}_{50}$ values as the inhibition did not exceed $50 \%$ at any concentration tested.

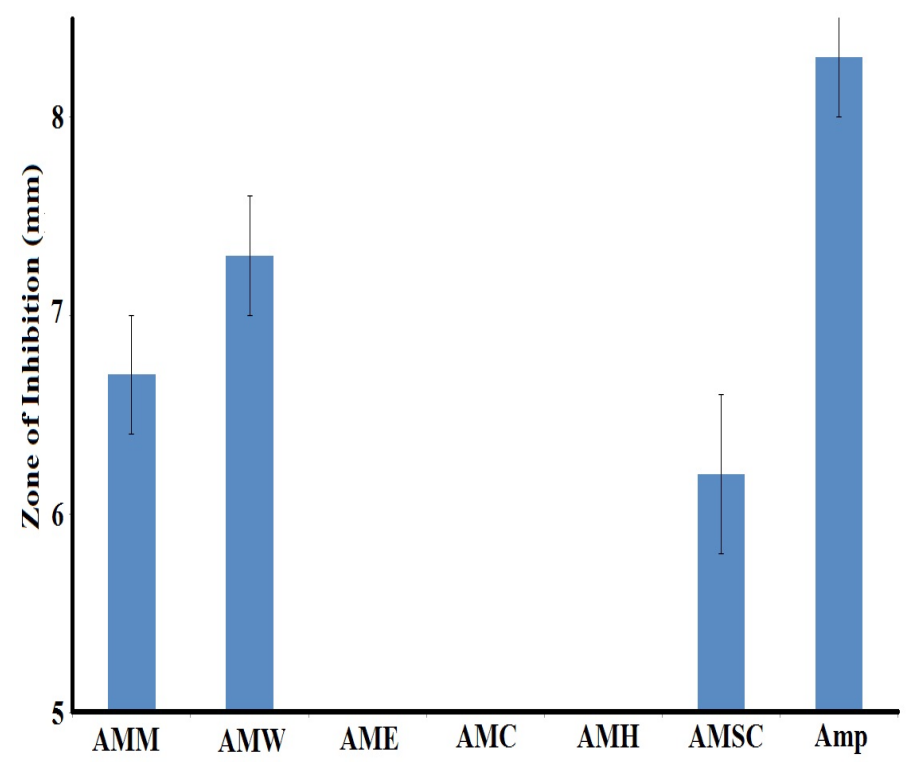

Figure 5: Antibacterial activity of $K$. senegalensis extracts measured as zones of inhibition $(\mathrm{mm})$ against a bacterial trigger of rheumatic fever (Streptococcus pyogenes). Results are expressed as mean \pm SEM of at least triplicate determinations. $\mathrm{AMM}=$ methanolic extract; $\mathrm{AMW}=$ aqueous extract; $\mathrm{AME}$ = ethyl acetate extract; $\mathrm{AMC}=$ chloroform extract; $\mathrm{AMH}$ = hexane extract; AMSC $=$ SFE extract; Amp = ampicillin control $(10 \mu \mathrm{g})$.

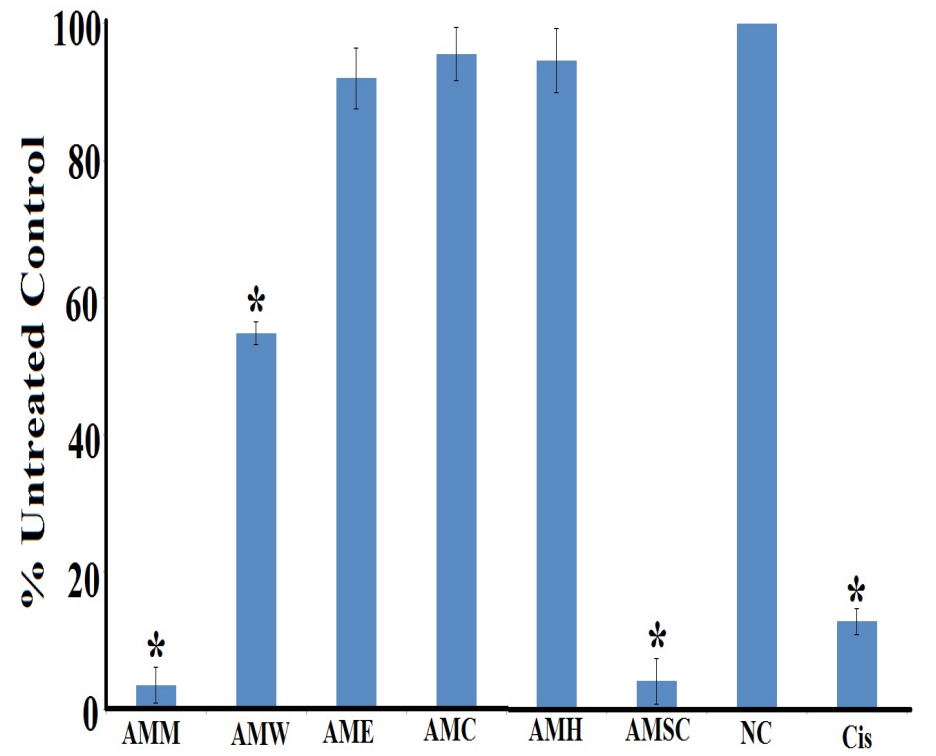

Figure 7: Anti-proliferative activity of $K$. senegalensis extracts and untreated controls against Caco- 2 carcinoma cells measured as percentages of the untreated control cells. Results are expressed as mean percentages \pm SEM of at least triplicate determinations. ${ }^{*}$ indicates results that are significantly different to the untreated control $(p<0.01)$. AMM = methanolic extract; AMW $=$ aqueous extract; $\mathrm{AME}=$ ethyl acetate extract; $\mathrm{AMC}=$ chloroform extract; $\mathrm{AMH}=$ hexane extract; $\mathrm{AMSC}=\mathrm{SFE}$ extract; $\mathrm{NC}=$ negative control; $\mathrm{Cis}=$ cisplatin control $(50 \mathrm{mg} / \mathrm{mL})$.

\section{Inhibition of cancer cell proliferation}

The $K$. senegalensis extracts were tested against 2 cancer cell lines (Caco2 colorectal carcinoma cells, Figure 7; HeLa cervical cancer cells, Figure 8 ) to determine their ability to inhibit cancer cell growth. The methanol, water and SFE extracts displayed potent inhibitory activity against Caco2 cells (Figure 7). Indeed, Caco-2 cellular proliferation was inhibited to

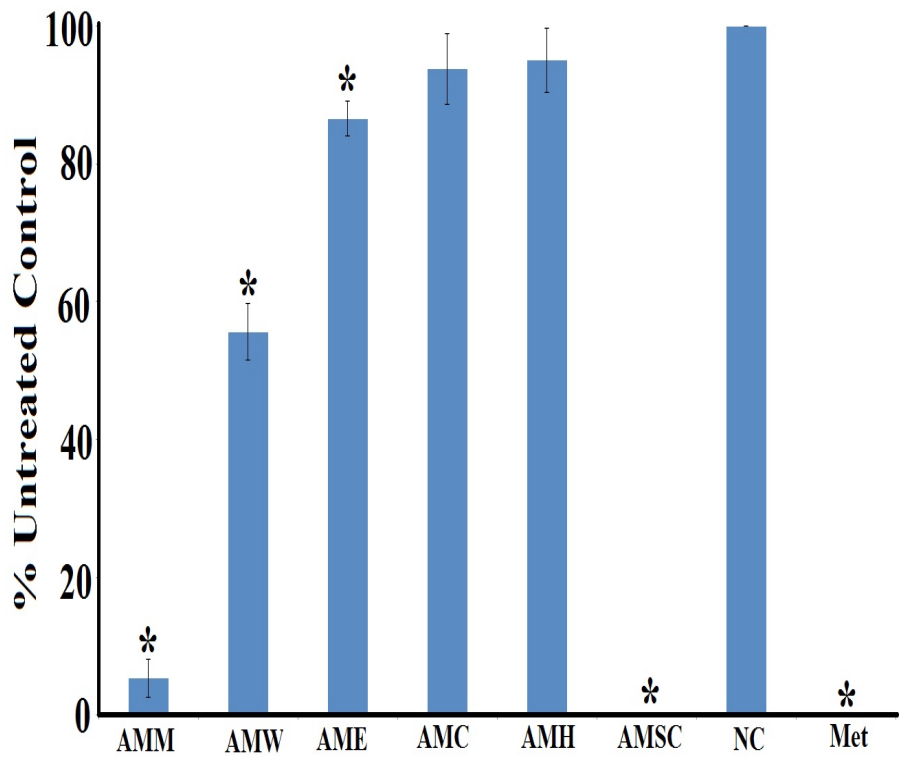

Figure 6: Inhibitory activity of K. senegalensis extracts against Giardia duodenalis trophozoites measured as a percentage the untreated control. Results are expressed as mean \pm SEM of at least triplicate determinations. * indicates results that are significantly different to the untreated control $(p<0.01)$. AMM $=$ methanolic extract; $\mathrm{AMW}$ = aqueous extract; $\mathrm{AME}$ = ethyl acetate extract; $\mathrm{AMC}=$ chloroform extract; $\mathrm{AMH}=$ hexane extract; $\mathrm{AMSC}=\mathrm{SFE}$ extract; $\mathrm{NC}=$ negative control; $\mathrm{PC}=$ metronidazole control $(50 \mu \mathrm{g} / \mathrm{mL})$.

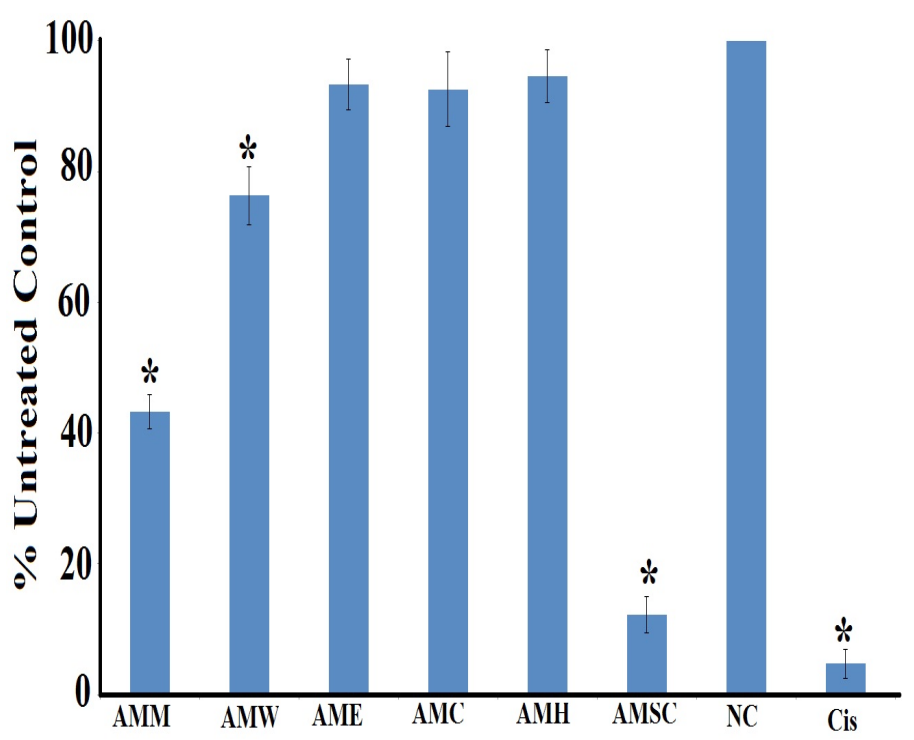

Figure 8: Anti-proliferative activity of $K$. senegalensis extracts and untreated controls against HeLa carcinoma cells measured as percentages of the untreated control cells. Results are expressed as mean percentages \pm SEM of at least triplicate determinations. * indicates results that are significantly different to the untreated control $(p<0.01)$. AMM = methanolic extract; AMW $=$ aqueous extract; $\mathrm{AME}=$ ethyl acetate extract; $\mathrm{AMC}=$ chloroform extract; $\mathrm{AMH}=$ hexane extract; $\mathrm{AMSC}=\mathrm{SFE}$ extract; $\mathrm{NC}=$ negative control; $\mathrm{Cis}=$ cisplatin control $(50 \mathrm{mg} / \mathrm{mL})$. 
approximately $4 \%$ of the untreated control cell growth by the methanolic and subcritical extracts (Figure 7). The aqueous extracts were also effective at inhibiting Caco-2 proliferation (to approximately $55 \%$ of untreated cell proliferation). In contrast, the ethyl acetate, chloroform and hexane extracts did not significantly affect Caco-2 cell proliferation. Inhibition of proliferation by the methanol, water and subcritical extracts was dose dependent, with the level of inhibitory activity decreasing at lower concentrations.

The K. senegalensis extracts also inhibited the proliferation of HeLa cells (Figure 8), albeit with lower efficacy than was evident with the Caco-2

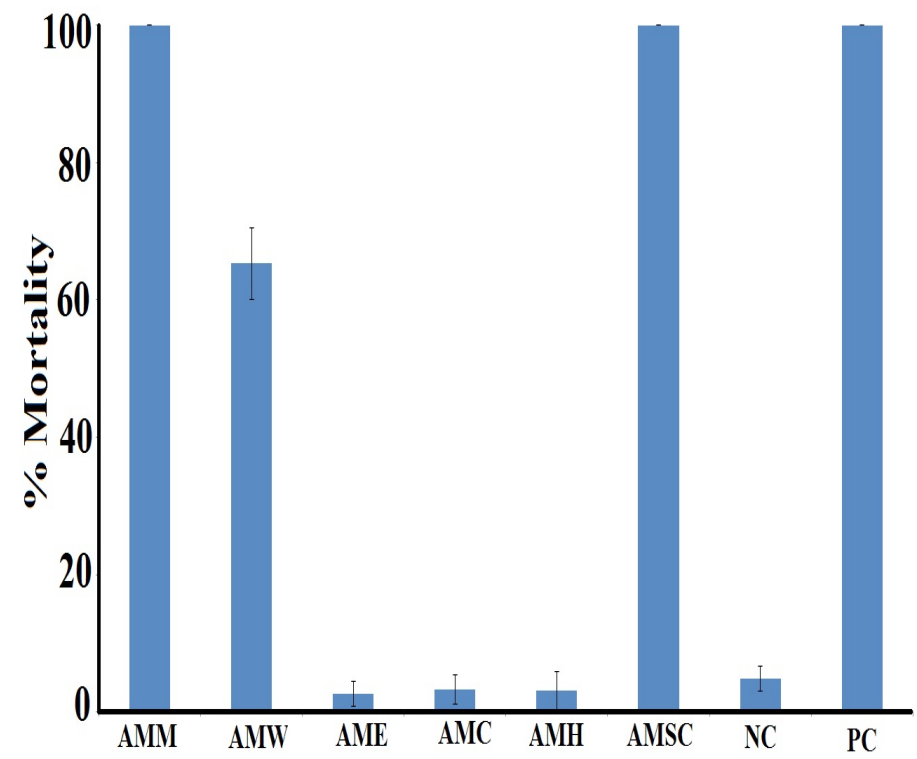

Figure 9: The lethality of $K$. senegalensis extracts and potassium dichromate $(1000 \mu \mathrm{g} / \mathrm{mL})$ and artificial seawater controls towards Artemia franciscana nauplii after 24 hours exposure. Results are expressed as mean \pm SEM of at least triplicate determinations. $\mathrm{AMM}=$ methanolic extract; $\mathrm{AMW}=$ aqueous extract; $\mathrm{AME}=$ ethyl acetate extract; $\mathrm{AMC}=$ chloroform extract; $\mathrm{AMH}=$ hexane extract; AMSC = SFE extract; NC = negative (seawater) control; $\mathrm{PC}=$ potassium dichromate control $(1000 \mu \mathrm{g} / \mathrm{mL})$.

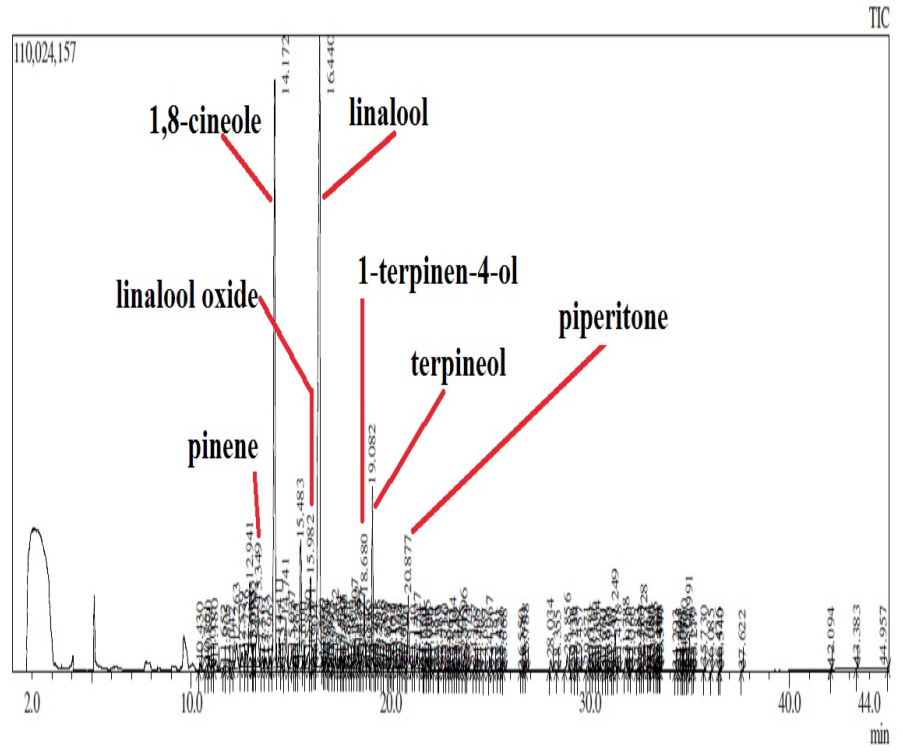

Figure 10: Head space gas chromatogram of a $0.5 \mu \mathrm{L}$ injection of the $K$. senegalensis bark SFE extract. The extract was dried and resuspended in methanol. Major phytochemical components are identified in the chromatogram. cells. The SFE K. senegalensis extract was the most potent inhibitor of HeLa cell proliferation, inhibiting to approximately $12 \%$ of the untreated control cell growth. In contrast, the methanolic and aqueous extracts inhibited HeLa cell proliferation to approximately 43 and $76 \%$ of the untreated control cell growth respectively. Inhibition of proliferation by the methanol extract was dose-dependent, with the level of inhibitory activity decreasing at lower concentrations.

The $K$. senegalensis extracts were further tested over a range of concentrations to determine the $\mathrm{IC}_{50}$ values (Table 3 ) for each extract against Caco-2 and HeLa proliferation. Inhibition of proliferation was dosedependent for all extracts, with the level of inhibitory activity decreasing at lower concentrations (Table 3). The methanolic and SFE K. senegalensis extracts were particularly potent HeLa anti-proliferative agents, with $\mathrm{IC}_{50}$ values of 155 and $174 \mu \mathrm{g} / \mathrm{mL}$, respectively. These extracts were similarly potent inhibitors of Caco- 2 proliferation, with $\mathrm{IC}_{50}$ values calculated of 268 and $470 \mu \mathrm{g} / \mathrm{mL}$, respectively.

\section{Quantification of toxicity}

K. senegalensis bark extracts were diluted to $4000 \mu \mathrm{g} / \mathrm{mL}$ (to give a bioassay concentration of $2000 \mu \mathrm{g} / \mathrm{mL}$ ) in artificial seawater for toxicity testing in the Artemia nauplii lethality bioassay. For comparison, the reference toxin potassium dichromate was also tested in the bioassay. Potassium dichromate was rapid in its induction of mortality, with mortality evident within 4 hours of exposure (unpublished results). The K. senegalensis extracts were slower at inducing mortality, with $\geq 12$ hours needed for mortality induction. Despite the slower onset of mortality, the methanol, water and SFE extracts induced mortality significantly above that of the artificial seawater control (Figure 9). Table 3 shows the extract and control toxin concentrations required to achieve $50 \%$ mortality $\left(\mathrm{LC}_{50}\right)$ at various times. All of the extractions also had $\mathrm{LC}_{50}$ values substantially $>1000 \mu \mathrm{g} / \mathrm{mL}$. As toxicity of crude plant extracts has previously been defined as $24 \mathrm{LC}_{50}$ values $<1000 \mu \mathrm{g} / \mathrm{mL},{ }^{37}$ all of the K. senegalensis extracts were deemed to be non-toxic.

\section{Non-targeted GC-MS headspace analysis of the subcritical $K$. senegalensis extract}

As the SFE K. senegalensis extract had potent bacterial growth inhibitory efficacy, anti-Giardial activity and carcinoma cell anti-proliferative activity (as determined by MIC and $\mathrm{IC}_{50}$; Table 3 ), it was deemed the most promising extract for further phytochemical analysis. Optimised GC-MS parameters were developed and used to examine the phytochemical composition of this extract. The resultant gas chromatograms are presented in Figure 10. Major peaks were evident in the SFE extract at approximately $14.2,15.5,15.9,16.4,19.1$ and $20.1 \mathrm{~min}$. Several smaller peaks were also evident throughout all stages of the chromatogram. In total, 92 unique mass signals were noted for the SFE K. senegalensis extract (Table 4). Putative empirical formulas and identifications were achieved for 72 (78\%) of these compounds by comparison with the database.

\section{DISCUSSION}

Plant remedies are becoming increasingly sought after in the treatment of a myriad of diseases and disorders due both to their perception of greater safety than synthetic drugs, and the failure of current drug regimens to effectively treat many diseases. This is especially true for the autoimmune inflammatory diseases. The current treatments utilising disease modifying anti-rheumatic drugs (DMARDs) to alleviate the symptoms of these diseases and/or alter the disease progression are not entirely effective and have been associated with numerous adverse effects. ${ }^{51}$ Furthermore, many of the current treatments are aimed at treating the symptoms without addressing the underlying causes and patho- 
genic mechanisms. Therefore, whilst these treatments may alleviate pain, redness, swelling, etc., they do not address the tissue degeneration which occurs as a consequence of the disease etiology. Furthermore, all of these drugs are used as treatments and there are currently no preventative therapy options. A better understanding of the mechanisms for initiation and progression of the autoimmune inflammatory diseases is important for developing new drugs to target specific processes and thus more effectively treat autoimmune inflammatory disease. A major focus of this study was to screen $K$. senegalensis extracts for the ability to inhibit the growth of bacterial triggers of some autoimmune inflammatory diseases. Our findings support previous studies which have also reported antibacterial properties for K. senegalensis extracts from other plant parts. ${ }^{12,13,16,18}$ The K. senegalensis bark extracts screened in our study were particularly potent inhibitors of $P$. mirabilis and $P$. vulgaris growth, with MIC values of several extracts substantially $<500 \mu \mathrm{g} / \mathrm{mL}$. This activity is noteworthy as $P$. mirabilis has been implicated in urinary tract infections (UTI's) and the induction of rheumatoid arthritis (RA). ${ }^{41,42}$ Thus, the K. senegalensis bark extracts have the potential to block RA before the induction of the immune response and inflammation, thus not only blocking the late phase symptoms, but also the tissue damage associated with RA. Furthermore, as these are crude extracts containing a number of known bioactive components, it is possible that they may also affect other phases of the rheumatoid arthritis disease process (e.g. regulation of cytokine production, immunomodulation, etc.) and thus may have pleuripotent effects. Further studies are required to test the effect of the extract on these other phases of the disease progression. If other therapeutic effects are subsequently detected, the K. senegalensis bark extracts may be a particularly attractive option for chronic sufferers of this disease, to block its onset as well as treating its symptoms once it is initiated.

The K. senegalensis bark extracts were similarly potent inhibitors of $K$. pneumoniae growth, with MIC values as low as $167 \mu \mathrm{g} / \mathrm{mL}$ (methanolic extract against the reference strain), indicating that it may also be useful in the prevention of ankylosing spondylitis. Whilst ankylosing spondylitis affects different tissue than rheumatoid arthritis, it has a similar multiple phased progression. ${ }^{43}$ The K. senegalensis bark extracts may therefore also have further effects on other phases of ankylosing spondylitis disease. Indeed, it is possible that the extract may also modulate cytokine production and therefore also block later inflammatory disease events, although this has yet to be tested for our extracts. The K. senegalensis bark extracts were also good inhibitors of $A$. baylyi and P. aeruginosa growth, with MIC values of several extracts $<1000 \mu \mathrm{g} / \mathrm{mL}$. These extracts may therefore be useful in the prevention and treatment of multiple sclerosis. Indeed, MIC values of 212 and $659 \mu \mathrm{g} / \mathrm{mL}$ were determined for the methanolic extract against clinical strains of A. baylyi and P. aeruginosa, respectively. In contrast, the $K$. senegalensis extracts were substantially less potent inhibitors of $S$. pyogenes growth. Indeed, only the methanolic, aqueous and subcritical extracts inhibited $S$. pyogenes growth to any extent. Furthermore, the MIC values for each of these extracts were substantially $>1000 \mu \mathrm{g} / \mathrm{mL}$, indicating moderate inhibitory activity. As $S$. pyogenes can cause a variety of diseases including streptococcal pharyngitis, impetigo and rheumatic heart disease, depending on which tissue it infects, these extracts may be useful in the treatment and prevention of these diseases.

Noteably, the therapeutic properties of an extract in the treatment of autoimmune diseases may be of greater efficacy as synergistic actions may exist between various therapeutic mechanisms (antibacterial, anti-inflammatory, antioxidant, immune-stimulatory, etc.), providing combined effects on these complex diseases. Thus, whilst the bacterial growth inhibitory studies reported here indicate the potential of the $K$. senegalensis extracts in the treatment and prevention of these autoimmune diseases, the activity may be more profound due to combinatorial effects and further studies are required to examine the effects of these extracts on later phases of these diseases. Furthermore, this study has only tested these extracts against some microbial triggers of 4 autoimmune diseases (rheumatoid arthritis, ankylosing spondylitis, multiple sclerosis and rheumatic fever). The microbial triggers for several other autoimmune inflammatory disorders are also known. For example, Borrelia burgdorferi is linked with Lyme disease. ${ }^{52}$ Whilst microbial triggers have also been postulated for lupus, the specific causative agents are yet to be identified. Similarly, members of the Enterobacteriaceae family are associated with Graves' disease and Kawasaki syndrome. Mycoplasma pneumoniae is associated with several demyelinating diseases ${ }^{53}$ It would be interesting to extend our studies to also screen for the ability of the extracts to block these microbial triggers of autoimmune diseases.

GC-MS headspace analysis of the SFE K. senegalensis extract detected a number of interesting compounds, including a wide diversity of terpenoids. Monoterpenoids were particularly prevalent, with 2-hydroxy-1,8cineole (Figure 11a), $\beta$-pinene (Figure 11b), terpinolene (Figure 11c), 1,8-cineole (Figure 11d), $\alpha$-pinene (Figure 11e), pseudolimonene (Figure 11f), linalool oxide (Figure 11g), linalool (Figure 11h), linalool methyl ether (Figure 11i), pinocarveol (Figure 11j), $\delta$-terpineol (Figure 11k), 1-terpinen-4-ol (Figure 11l), $\alpha$-terpineol (Figure 11m), $\alpha$-thujenal (Figure 11n), neral (Figure 11o), piperitone (Figure 11p), eugenol (Figure 11q) and methyleugenol (Figure 11r) putatively identified by comparison to a commercial database. Monoterpenes have been reported to exert a wide variety of biological effects including antibacterial, antifungal, anti-inflammatory and anti-tumour activities ${ }^{54}$ and therefore are likely to contribute to the growth inhibitory activity against the bacterial triggers of the autoimmune diseases reported here. Indeed, many of the monoterpenoids putatively identified in our study have been previously reported to have potent broad spectrum antibacterial activity ${ }^{54}$ Further studies have reported that a wide variety of monoterpenoids inhibit the growth of an extensive panel of pathogenic and food spoilage bacteria. ${ }^{55}$ Interestingly, several of these monoterpenoids have also been reported to suppress NF- $\kappa$ B signaling (the major regulator of inflammatory diseases). ${ }^{56-59}$ Thus, the monoterpenoid components may have a pleuripotent mechanism in blocking the autoimmune inflammatory diseases and relieving its symptoms by acting on both the initiator and downstream inflammatory stages of the disease.

Several sesquiterpenoids were also detected in the SFE K. senegalensis extract. Comparison to a commercial database resulted in putative identification of cycloisolongifol-5-ol (Figure 12a), italicene ether (Figure 12b), a-dehydro-ar-himachalene (Figure 12c), longifolenaldehyde (Figure 12d), globulol (Figure 12e), spathulenol (Figure 12f), ledol (Figure 12g), $\gamma$-eudesmol (Figure 12h), guai-1(10)-en-11-ol (Figure 12i), isocalamenediol (Figure 12j), cyperenone (Figure 12k), phthalic acid, diisobutyl ester (Figure 12l) and dibutyl phthalate (Figure 12m). Previous studies have reported bacterial growth inhibitory activities for many sesquiterpenoids against a wide panel of pathogenic bacteria, with MIC values as low as $4 \mu \mathrm{g} / \mathrm{mL}$ reported. ${ }^{60-62}$ Similar compounds were also detected in the SFE K. senegalensis extract. Thus, sesquiterpenoids are also likely to contribute to the growth inhibitory activity determined in our study.

Potent growth inhibition of the food/water borne gastrointestinal parasite Giardia duodenalis was also noted for the K. senegalensis bark extracts in our study. Giardial infection (giardiasis) is a re-emerging disease which afflicts large numbers of individuals worldwide, with higher incidence in countries with poorer socio-economic conditions, inadequate sanitary conditions, untreated water supplies and poor diet. ${ }^{48}$ Whilst generally not fatal, giardiasis results in debilitating symptoms including bloating, diarrhoea, excess gas, loss of appetite, loose and watery stool, stomach cramps and haematuria. Currently, there are only a narrow range of drugs effective against giardiasis, including quinalones and im- 


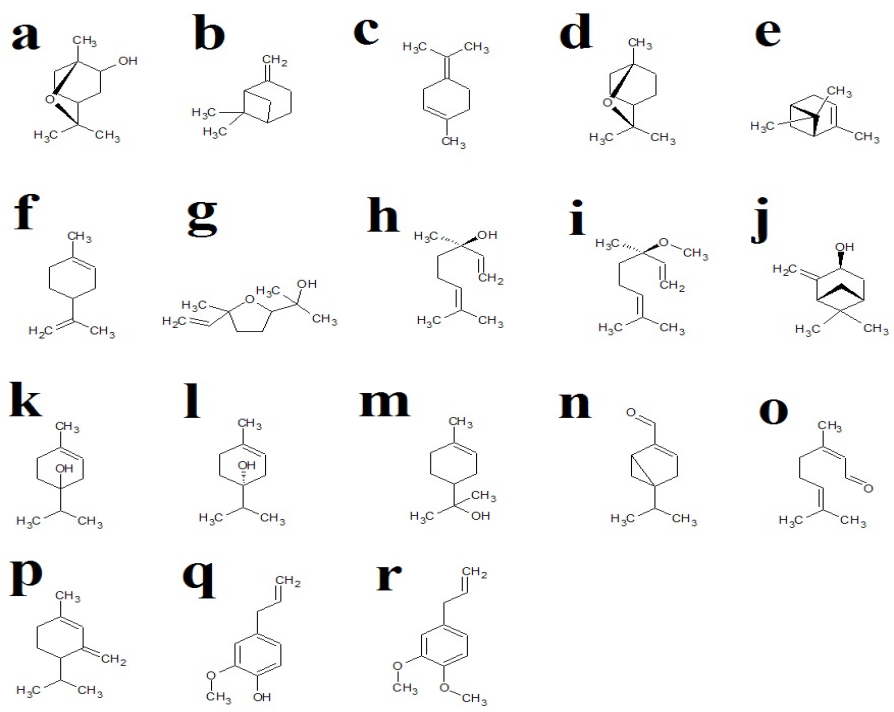

Figure 11: Monoterpenoid components of the SFE $K$. senegalensis extract: (a) 2-hydroxy-1,8-cineole, (b) $\beta$-pinene, (c) terpinolene, (d) 1,8-cineole, (e) a-pinene, (f) pseudolimonene, (g) linalool oxide, (h) linalool, (i) linalool, methyl ether, (j) pinocarveol, (k) $\delta$-terpineol, (l) 1-terpinen-4-ol, (m) a-terpineol, (n) a-thujenal, (o) neral, (p) piperitone, (q) eugenol, ( $r$ ) methyleugenol.

idazole derivatives. None of these drugs is ideal as they produce unpleasant side effects including nausea, vertigo, vomiting, diarrhoea and hallucinations. ${ }^{33,48}$ Furthermore, increasing reports of the failure of current treatments to address this disease indicates a developing drug resistance of several Giardia species. ${ }^{48}$ Recent studies have highlighted the potential of plant medicines and have demonstrated that some plant components are very effective inhibitors of Giardia duodenalis growth with similar potency to the gold standard drug metronidazole. ${ }^{33}$ Our studies demonstrate that $K$. senegalensis bark also possesses anti-Giardial activity. Whilst, further studies are required to identify the active component(s), previous studies have identified several similar terpenoids in plants ${ }^{49}$ and marine sponges ${ }^{50}$ which inhibit the growth of parasitic protozoans. The former of these studies is of particular note as it correlates trypanocidal activity with similar sesquiterpenoid lactones as those detected in our study.

Anti-proliferative activity against Caco-2 and HeLa carcinoma cell lines cells was noted for the $K$. senegalensis bark extracts (especially for the methanolic and SFE extracts), with $\mathrm{IC}_{50}$ values generally $150-500 \mu \mathrm{g} / \mathrm{mL}$. These findings support and extend previous studies examining the anticancer effects of other K. senegalensis extracts against different carcinoma cell lines. K. senegalensis stem bark solvent extracts significantly inhibited the growth of HCT-15, HT-29 and HCA-7 colorectal carcinoma cells. ${ }^{6,14}$ This inhibition is comparable to the inhibition of the Caco-2 colorectal cells in our study. Furthermore, that study also examined the inhibitory mechanism and determined that the bark extracts had both antiproliferative and pro-apoptotic activities. Similarly, the growth of $\mathrm{SiHa}$ (cervical cancer cells) was inhibited by K. senegalensis stem bark extracts, ${ }^{13}$ paralleling the HeLa cervical carcinoma proliferation results reported in our study. The previous study also examined the phytochemistry of the bark extracts and correlated the antiproliferative activity with limonoids. Interestingly, similar limonoids were not detected in the $K$. senegalensis bark extracts examined in our study. However, the GC-MS headspace analysis employed for phytochemical characterisation in our studies utilised a $45-450 \mathrm{~m} / \mathrm{z}$ mass range cut off. Thus, larger limonoid triterpenoid molecules would not have been detected under these conditions and may still be present. Our qualitative studies did detect relative-
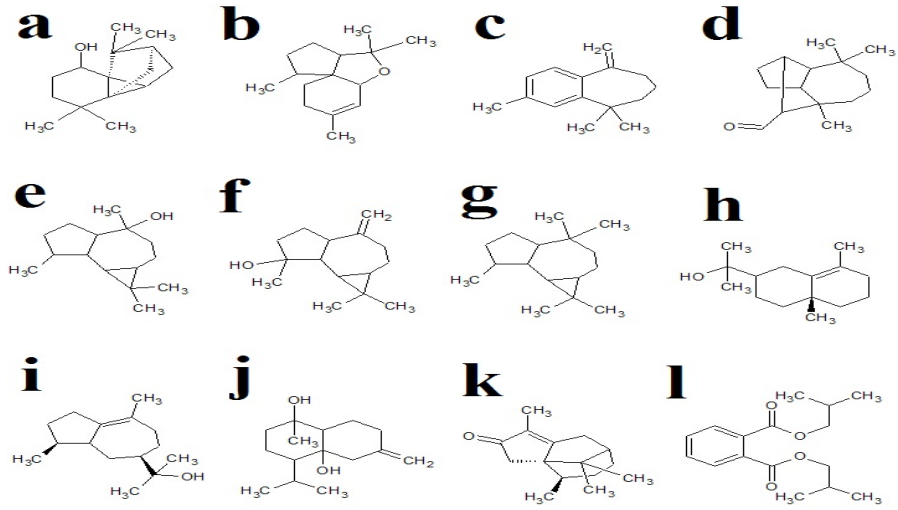

$\mathbf{m}$

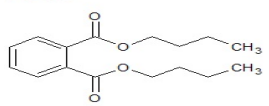

Figure 12: Sesquiterpenoid components of the SFE $K$. senegalensis extract: (a) cycloisolongifol-5-ol, (b) italicene ether, (c) a-dehydro-ar-himachalene, (d) longifolenaldehyde, (e) globulol, (f) spathulenol, (g) ledol, (h) y-eudesmol, (i) guai-1(10)-en-11-ol, (j) isocalamenediol, (k) cyperenone, (l) phthalic acid, diisobutyl ester, (m) di-butyl phthalate.

ly high triterpenoid levels, particularly in the most potent methanolic, aqueous and subcritical extracts. It is therefore likely that these extracts may contain substantial levels of similar limonoids, khayanolides and other triterpenoids as previously reported for the bark extracts. ${ }^{13}$ Phytochemical isolation and identification studies using different analytical methods are required to confirm this.

Whilst this study provides insight into the phytochemical compositions of the $K$. senegalensis extracts, it is noteworthy that no single technique will detect and identify all compounds responsible for any therapeutic property in an extract. Our study utilised a GC-MS headspace technique to examine the extracts. This technique was chosen as many previous studies have highlighted the presence of terpenoid components in extracts produced using other K. senegalensis extracts (Table 1; Figure 1). As detection of these volatile, relatively nonpolar compounds is suited to GC-MS headspace analysis, this was deemed to be an appropriate analytical tool for this study. However, these extracts are likely to contain many more polar compounds that were not detected in this study. Thus, further studies using LC-MS analysis are required to further characterise the higher polarity components of the K. senegalensis bark extracts.

The results of this study indicate that the K. senegalensis bark extracts examined in this report are worthy of further study due to their antibacterial and anti-Giardial activities and ability to block cancer cell proliferation. None of the K. senegalensis extracts displayed significant toxicity towards $A$. franciscana. Indeed, $\mathrm{LC}_{50}$ values substantially in excess of $1000 \mu \mathrm{g} / \mathrm{mL}$ were measured for all extracts (extracts with $\mathrm{LC}_{50}$ values $>1000 \mu \mathrm{g} / \mathrm{mL}$ in the Artemia franciscana nauplii bioassay are defined as being non-toxic).$^{37}$ Further evaluation of the antimicrobial and anticancer properties of these extracts is warranted. Likewise, bioactivity driven purification studies are needed to examine the mechanisms of action of the bioactive agents. Whilst the extracts examined in this report have potential as antimicrobial and anticancer agents, caution is needed before they can be applied to medicinal purposes.

\section{CONCLUSION}

The results of this study partially validate the traditional usage of $K$. senegalensis extracts in multiple traditional African medicinal systems to 
treat bacterial and protozoal diseases as well as some cancers. Bioactivity driven purifications of the active components and an examination of the mechanisms of action of these agents is warranted.

\section{HIGHLIGHTS OF PAPER}

- Methanolic and SFE K. senegalensis extracts were potent inhibitors of Proteus spp. growth (MICs approximately $200 \mu \mathrm{g} / \mathrm{mL}$ ).

- These extracts were also potent inhibitors of $K$. pneumoniae (MICs $170-400 \mu \mathrm{g} / \mathrm{mL}$ ) and A. baylyi (MICs 200-700 $\mu \mathrm{g} / \mathrm{mL}$ ).

- The methanolic and SFE extracts were moderate inhibitors of $P$. aeruginosa and S. pyogenes (MICs $>1000 \mu \mathrm{g} / \mathrm{mL}$ ).

- The methanolic and SFE extracts were potent inhibitors of Giardia duodenalis proliferation ( $\mathrm{IC}_{50} 187$ and $328 \mu \mathrm{g} / \mathrm{mL}$, respectively).

- Proliferation of Caco-2 and HeLa carcinoma cells were inhibited by the methanolic and SFE K. senegalensis extracts with $\mathrm{IC}_{50}$ values $150-470 \mu \mathrm{g} /$ $\mathrm{mL}$.

- All K. senegalensis bark extracts were non-toxic in the Artemia nauplii assay.

\section{ACKNOWLEDGEMENT}

Financial support for this work was provided by the Environmental Futures research Institute and the School of Natural Sciences, Griffith University.

\section{CONFLICT OF INTEREST}

None

\section{ABBREVIATIONS USED}

DMSO: Dimethyl sulfoxide; $\mathrm{IC}_{50}$ : The concentration required to achieve $50 \%$ effect; $\mathrm{LC}_{50}$ : The concentration required to achieve $50 \%$ mortality; MIC: minimum inhibitory concentration.

\section{REFERENCES}

1. Mahomoodally MF. Traditional medicines in Africa: An appraisal of ten potent African medicinal plants. Evidence Based Complementary and Alternative Medicine 2013; e617459. http://dx.doi.org/10.1155/2013/617459. https://doi. org/10.1155/2013/617459.

2. Moyo M, Aremu AO, Van Staden J. Medicinal plants: An invaluable, dwindling resource in sub-Saharan Africa. Journal of Ethnopharmacology 2015;174:595606. https://doi.org/10.1016/j.jep.2015.04.034; PMid:25929451.

3. Orwa C, Mutua A, Kindt R, et al. Agroforestree Database: a tree reference and selection guide version 4.0. World Agroforestry Centre, Kenya; http://www. worldagroforestry.org/resources/databases/agroforestree : cited 27 June 2016 .

4. Gill LS. Ethnomedical Uses of Plants in Nigeria. University of Benin Press; Benin, Nigeria: 1992.

5. Iwu M. Hankbook of African Medicinal Plants, Pharmacognostical Profile of Selected Medicinal Plants. CRC Press Inc; Boca Raton, USA: 1993

6. Androulakis XM, Muga SJ, Chen F, et al. Chemoprotective effects of Khaya senegalensis bark extract on human colorectal cancer. Anticancer Researc 2006;26(3B):2397-406. ; PMid:16821623.

7. Abdelgaleil SAM, Iwagawa T, Doe $M$, et al. Antifungal limonoids from the fruits of Khaya senegalensis. Fitoterapia 2004;75(6):566-572. https://doi.org/10.1016/j fitote.2004.06.001; PMid:15351110.

8. Abdelgaleil SAM, Okamura $H$, Iwagawa $T$, et al. Khayanolides, rearranged phragmalin limonoid antifeedants from Khaya senegalensis. Tetrahedron. 2001;57(1):119-26. https://doi.org/10.1016/S0040-4020(00)00994-7.

9. Makut MD, Gyar SD, Pennap GRI, et al. Phytochemical screening and antimicrobial activity of the ethanolic and methanolic extracts of the leaf and bark of Khaya senegalensis. African Journal of Biotechnology. 2008;7(9):1216-9.

10. Kubmarawa D, Khan ME, Punah AM, et al. Phytochemical screening and antimicrobial efficacy of extracts from Khaya senegalensis against human pathogenic bacteria. African Journal of Biotechnology 2008;7(24):4563-6.

11. Kayser O, Abreu PM. Antileishmania and immunostimulating activities of two dimeric proanthocyanidins from Khaya senegalensis. Pharmaceutical Biology 2001;39(4):284-8. https://doi.org/10.1076/phbi.39.4.284.5921

12. Kolawole OT, Kolawole SO, Ayankunle AA, et al. Anti-hyperglycemic effect of
Khaya senegalensis stem bark aqueous extract in Wistar rats. European Journal of Medicinal Plants. 2012;2(1):66-73. https://doi.org/10.9734/EJMP/2012/934

13. Zhang $H$, Wang $X$, Chen $F$, et al. Anticancer activity of limonoid from Khaya senegalensis. Phytotherapy Research 2007;21(18):731-4. https://doi.org/10.1002/ ptr.2148 ; PMid:17450502.

14. El Tahir A, Satti GMH, Khalid SA. Antiplasmodial activity of selected Sudanese medicinal plants with emphasis on Maytenus senegalensis (Lam.) Exell. Jour nal of Ethnopharmacology 1999;64(3):227-33. https://doi.org/10.1016/S03788741(98)00129-9.

15. Umar IA, Ibrahim MA, Fari NA, et al. In-vitro and in-vivo anti-Trtpanosoma evansi activities of extracts from different parts of Khaya senegalensis. Journal of Cell and Animal Biology 2010;4(6):91-5

16. Ibrahim MA, Njoku GC, Sallau AB. In vivo activity of stem bark aqueous extract of Khaya senegalensis against Trypanosoma brucei. African Journal of Biotechnology 2008;7(5):661-3.

17. El-Aswad AF, Abdelgaleil SAM, Nakatani M. Feeding deterrant and growth inhibitory properties of limonoids from Khaya senegalensis against the cotton leafworm, Spodoptera littoralis. Pest Management Science 2003: 60: 199-203. https://doi.org/10.1002/ps.818; PMid:14971689.

18. Khalid SA, Friedrichsen GM, Kharazmi A, et al. Limonoids from Khaya senegalensis. Phytochemistry. 1998:49(6):1769-72. https://doi.org/10.1016/S00319422(98)00284-2.

19. Yuan CM, Zhang Y, Tang GH, et al. Senegalensions A-C. three limonoids from Khaya senegalensis. Chemistry An Asian Journal 2012:7(9):2014-7. https://doi. org/10.1002/asia.201200320; PMid:22733621.

20. Yuan $T$, Zhang $C R$, Yang $S P$ et al. Limonoids and triterpenoids from Khaya senegalensis. Journal of Natural Products. 2010;73(4):669-74. https://doi. org/10.1021/np1000158; PMid:20222670.

21. Zhang $H$, Tan J, VanDerveer $D$, et al. Khayanolides from African mahogany Khaya senegalensis (Meliaceae): A revision. Phytochemistry. 2009;70(2):294-9 https://doi.org/10.1016/j.phytochem.2008.12.004; PMid:19136128.

22. Roy A, Saraf S. Limonoids: Overview of significant bioatctive triterpenes distributed in plants kingdom. Biological and Pharmaceutical Bulletin 2006;29(2):191 201. https://doi.org/10.1248/bpb.29.191; PMid:16462017.

23. Cock IE, Kalt FR. GC-MS analysis of a Xanthorrhoea johnsonii leaf extract displaying apparent anaesthetic effects. Journal of Natural Pharmaceuticals 2012·3(2):78-88. DOI: 10.4103/2229-5119.102749 https://doi.org/10.4103/22295119.102749 .

24. Vallette L, Rabadeaux C Sirdaarta J, et al. An upscaled extraction protocol for Tasmannia lanceolata (Poir.) A.C. Sm.: Anti-bacterial, anti-Giardial and anti cancer activity. Pharmacognosy Communications 2016;6(4) DOI: 10.5530/pc.2016

25. Kalt FR, Cock IE. GC-MS analysis of bioactive Petalostigma extracts: Toxicity, antibacterial and antiviral activities. Pharmacognosy Magazine. 2014;10(37 Suppl):S37-S48. DOI: 10.4103/0973-1296.127338 https://doi.org/10.4103/09731296.127338

26. Wright $\mathrm{MH}$, Matthews $\mathrm{B}$, Greene AC, et al. Metabolomic profiling of polar Tasmannia lanceolata extracts shown to inhibit Bacillus anthracis growth. Pharmacognosy Communications 2016. In press.

27. Cock IE, Kukkonen L. An examination of the medicinal potential of Scaevola spinescens: Toxicity, antibacterial and antiviral activities. Pharmacognosy Research. 2011;3:85-94. DOI: 10.4103/0974-8490.8195; https://doi. org/10.4103/0974-8490.81955.

28. Vesoul J, Cock IE. The potential of Bunya nut as an antibacterial food agent. Pharmacognosy Communications 2012;2(1):72-9. DOI: 10.5530/pc.2012.1.13 https://doi.org/10.5530/pc.2012.1.13

29. Sautron C, Cock IE. Antimicrobial activity and toxicity of Syzygium australe and Syzygium leuhmanii fruit extracts. Pharmacognosy Communication 2014;4(1):53-60. DOI: 10.5530/pc.2014.1.8. https://doi.org/10.5530/pc.2014.1.8.

30. Chikowe G, Mpala L, Cock IE. Antibacterial activity of selected Australian Syzy gium species. Pharmacognosy Communications 2013;3(4):77-83.

31. Boyer $\mathrm{H}$, Cock IE. Evaluation of the potential of Macademia integriflora extracts as antibacterial food agents. Pharmacognosy Communications 2013;3(3):53-62. DOI: $10.5530 /$ pc. 2013.3.10.

32. Winnett $\mathrm{V}$, Boyer $\mathrm{H}$, Sirdaarta $\mathrm{J}$, et al. The potential of Tasmannia lanceolata as a natural preservative and medicinal agent: Antimicrobial activity and toxicity. Pharmacognosy Communications 2014;2014;4(1):42-52. DOI: 10.5530/ pc.2014.1.7 https://doi.org/10.5530/pc.2014.1.7

33. Rayan P, Matthews B, McDonnell PA, et al. Terminalia ferdinandiana extracts as inhibitors of Giardia duodenalis proliferation: a new treatment for giardiasios. Parasitology Research 2015:114(7):2611-20. DOI: 10.1007/s00436-015-4465-4 https://doi.org/10.1007/s00436-015-4465-4.

34. Rayan P, Matthews B, McDonnell PA, et al. Phytochemical analysis of Tas mannia lanceolata extracts which inhibit Giardia duodenalis proliferation. Pharmacognosy Journal 2016:8(3):291-9. DOI: 10.5530/pj.2016.3.19 https://doi. org/10.5530/pj.2016.3.19.

35. Jamieson N, Sirdaarta J, Cock IE. The anti-proliferative properties of Australian plants with high antioxidant capacities against cancer cell lines. Pharmacog nosy Communications. 2014;4(4):71-82. DOI: 10.5530/pc.2014.4.8

36. Arkhipov A, Sirdaarta J, Rayan P, McDonnell PA, Cock IE. An examination of the 
antibacterial, antifungal, anti-Giardial and anticancer properties of Kigelia Africana fruit extracts. Phcog Commn. 2014;4(3):62-76. DOI: 10.5530/pc.2014.3.7 https://doi.org/10.5530/pc.2014.3.7.

37. Cock IE, Ruebhart DR. Comparison of the brine shrimp nauplii bioassay and the ToxScreen-II Test for the detection of toxicity associated with Aloe vera (Aloe barbadensis Miller) leaf extract. Pharmacognosy Journal 2009; 1: 98-101.

38. Ruebhart DR, Wickramasinghe W, Cock IE. Protective efficacy of the antioxidants vitamin $\mathrm{E}$ and Trolox ${ }^{\mathrm{TM}}$ against Microcystis aeruginosa, microcystin-LR and menadione toxicity in Artemia franciscana nauplii. Journal of Toxicology and Environmental Health Part A. 2009;72(24):1567-75. https://doi. org/10.1080/15287390903232459; PMid:20077231.

39. Sirdaarta J, Cock IE. Vitamin E and Trolox ${ }^{\mathrm{TM}}$ reduce toxicity of Aloe barbadensis Miller juice in Artemia franciscana nauplii but individually are toxic at high concentrations. Internet Journal of Toxicology 2008;5:(1)

40. Wright MH, Sirdaarta J, Matthews B, et al. Growth inhibitory activity of Kakadu plum extracts against the opportunistic pathogen Clostridium perfringens: New leads in the prevention and treatment of clostridial myonecrosis. Pharmacognosy Journal. 2016;8(2):144-52. DOI: 10.5530/pj.2016.2.8. https://doi.org/10.5530/ pj.2016.2.8.

41. Cock IE, Winnett V, Sirdaarta J, et al. The potential of selected Australian medicinal plants with anti-Proteus activity for the treatment and prevention of rheumatoid arthritis. Pharmacognosy Magazine. 2015;42(Supp1):S190-208. DOI: 10.4103/0973-1296.157734. https://doi.org/10.4103/0973-1296.157734.

42. Cock IE. The early stages of rheumatoid arthritis: New targets for the development of combinational drug therapies. OA Arthritis 2014;2(1):5

43. Cock IE. van Vuuren SF. The potential of selected South African plants with antiKlebsiella activity for the treatment and prevention of ankylosing spondylitis. Inflammopharmacology. 2015;23:21-35. DOI: 10.1007/s10787-014-0222-z https:// doi.org/10.1007/s10787-014-0222-z.

44. Ebringer $A$, Hughes $L$, Rashid $T$, et al. Acinetobacter immune response in multiple sclerosis. Etiopathogenetic role and its possible use as a diagnostic marker. JAMA Neurology. 2005;62(1):33-6

45. Rashid T, Ebringer A. Autoimmunity in rheumatic diseases is induced by microbial infections via cross reactivity or molecular mimicry. Autoimmune Disease 2012: Article ID 539282. DOI: 10.1155/2012/539282. https://doi org/10.1155/2012/539282.

46. Courtney R, Sirdaarta J, Matthews B, et al. Tannin components and inhibitory activity of Kakadu plum leaf extracts against microbial triggers of autoimmune inflammatory diseases. Pharmacognosy Journal 2015;7(1):18-31. DOI: 10.5530/ pj.2015.7.2. https://doi.org/10.5530/pj.2015.7.2.

47. Biggs I, Sirdaarta J, White A, et al. GC-MS analysis of frankincense extracts which inhibit the growth of bacterial triggers of selected autoimmune diseases. Pharmacognosy Communications 2015;6(1):10-22. DOI: 10.5530/pc.2016.1.3 https://doi.org/10.5530/pc.2016.1.3.

48. Harris JC, Plummer S, Lloyd D. Anti-giardial drugs. App Microbiol Biotechnol 2001;57:614-9. https://doi.org/10.1007/s002530100720.

49. Uchiyama N, Matsunaga K, Kiuchi F, et al. Trypanocidal terpenoids from Laurus nobilis L. Chemical and Pharmaceutical Bulletin 2002;50(11):1514-6. https://doi org/10.1248/cpb.50.1514; PMid:12419922.

50. Orhan I, Şener B, Kaiser M, et al. Inhibitory activity of marine sponge-derived natural products against parasitic protozoa. Marine Drugs 2010;8(1):47-58 https://doi.org/10.3390/md8010047 ; PMid:20161970 PMCid:PMC2817922.

51. Alataha D, Kapral T, Smolen JS. Toxicity profiles of traditional disease modifying antirheumatic drugs for rheumatoid arthritis. Ann Rheum Dis 2003:62:482-6. https://doi.org/10.1136/ard.62.5.482 ; PMCid:PMC1754550.

52. Beermann C, Wunderli-Allenspach $H$, Groscurth $P$, et al. Lipoproteins from Borrelia burgdorferi applied in liposomes and presented to dendritic cells induce CD8+ T-lymphocytes in vitro. Cell Immunol. 2000;201:124-31. https://doi. org/10.1006/cimm.2000.1640; PMid:10831321.

53. Kollef MH, West S, Davis DR, et al. Central and peripheral nervous system demyelination after infection with Mycoplasma pneumoniae. Evidence of an autoimmune process. Southern Med J 1991:84(10):1255-8. https://doi. org/10.1097/00007611-199110000-00022.

54. Cock IE. The phytochemistry and chemotherapeutic potential of Tasmannia lanceolata (Tasmanian pepper): A review. Pharmacognosy Communications 2013;3(4):13-25. DOI: 10.5530/pc.2013.4.3

55. Bakkali F, Averbeck S, Averbeck D, et al. Biological effects of essential oils - A review. Food and Chemical Toxicology 2008;46(2):446-75. https://doi. org/10.1016/j.fct.2007.09.106 ; PMid:17996351.

56. Salminen A, Lehtonen M, Suuronen T, et al. Terpenoids: Natural inhibitors of $\mathrm{NF}-\mathrm{kB}$ signalling with anti-inflammatory and anticancer potential. Cell and Molecular Life Sciences. 2008:65(19):2979-99. https://doi.org/10.1007/s00018-0088103-5; PMid:18516495.

57. Lu XG, Zhan LB, Feng BA et al. Inhibition of growth and metastasis of human gastric cancer implanted in nude mice by d-limonene. World Journal of Gastroenterology. 2004;10(14):2140-4. https://doi.org/10.3748/wjg.v10.i14.2140 PMCid:PMC4572353.

58. Crowell PL. Prevention and therapy of cancer by dietary monoterpenes. Journal of Nutrition. 1999;129(3):775S-877S. PMid:10082788.

59. Zhou JY, Tang FD, Mao GG, et al. Effect of a-pinene on nuclear translocation of NF-kB in THP-1 cells. Acta Pharmacologica Sinica 2004;25(4):480-4. PMid:15066217.

60. Huang M, Sanchez-MoreirasAM, Abel C, et al. The major volatile organic compound emitted from Arabidopsis thaliana flowers, the sesquiterpene (E)- $\beta$-caryophyllene, is a defense against a bacterial pathogen. New Phytologist. 2012;193(4):997-1008. https://doi.org/10.1111/j.1469-8137.2011.04001.x PMid:22187939.

61. Cane DE, Ke N. Epicubenol synthase. Origin of the oxygen atom of a bacterial sesquiterpene alcohol. Bioorganic and Medicinal Chemistry Letters 2000;10(2):105-7. https://doi.org/10.1016/S0960-894X(99)00650-2.

62. Rahman MM, Garvey M, Piddock LJV, et al. Antibacterial terpenes from the oleoresin of Commiphora molmol (Engl.). Phytotherapy Research 2008;22(10):135660. https://doi.org/10.1002/ptr.2501; PMid:18570217.

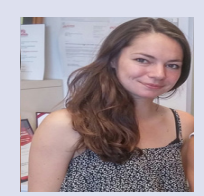

\section{ABOUT AUTHORS}

Ms Camille Rabadeaux: Is a postdraduate student at School of Biology, Ecole de Biologie Industrielle (EBI), Cergy, France. In 2015, she undertook a research project in Dr lan Cock's laboratory in the School of Natural Sciences at Griffith University examining the therapeutic properties of a variety of Australian native plants.

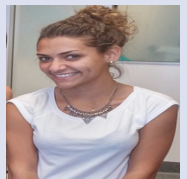

Ms Low Vallette: Is a postdraduate student at School of Biology, Ecole de Biologie Industrielle (EBI), Cergy, France. In 2015, she undertook a research project in Dr lan Cock's laboratory in the School of Natural Sciences at Griffith University examining the therapeutic properties of a variety of Australian native plants.

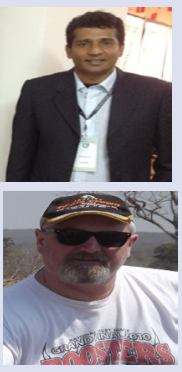

Joseph Sirdaarta: Is currently a PhD student at School of Natural Sciences, Griffith University, Australia under the supervision of Dr lan Cock. His research project examinines the anticancer properties of a variety of Australian native plants. He has also undertaken studies into antibacterial, antiprotozoal and anti-inflammatory properties of natural and traditional medicines, resulting in over 20 publications and 15 conference presentations.

Dr lan Cock: Leads a research team in the Environmental Futures Research Institute and the School of Natural Sciences at Griffith University, Australia. His research involves bioactivity and phytochemical studies into a variety of plant species of both Australian and international origin, including Aloe vera, South Asian and South American tropical fruits, as well as Australia plants including Scaevola spinescens, Pittosporum phylliraeoides, Terminalia ferdinandiana (Kakadu plum), Australian Acacias, Syzygiums, Petalostigmas and Xanthorrhoea johnsonii (grass trees). This range of projects has resulted in nearly 200 publications in a variety of peer reviewed journals.

Cite this Article: Rabadeaux C, Vallette L, Sirdaarta J, Davis C, Cock IE. An examination of the Antimicrobial and Anticancer Properties of Khaya senegalensis (Desr.) A. Juss. Bark Extracts. Pharmacogn J. 2017;9(4):504-18. 